\title{
UNCOVERING THE HETEROGENEOUS EFFECTS OF ECB UNCONVENTIONAL MONETARY POLICIES ACROSS EURO AREA COUNTRIES
}

\section{Pablo Burriel and Alessandro Galesi}

Documentos de Trabajo N. 1631

\section{BANCODE ESPAÑA}

Eurosistema

\section{6}
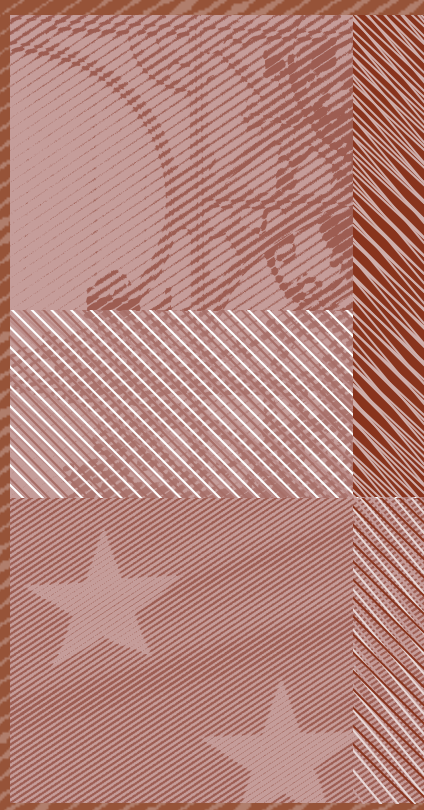
UNCOVERING THE HETEROGENEOUS EFFECTS OF ECB UNCONVENTIONAL

MONETARY POLICIES ACROSS EURO AREA COUNTRIES 
UNCOVERING THE HETEROGENEOUS EFFECTS OF ECB

UNCONVENTIONAL MONETARY POLICIES ACROSS EURO

AREA COUNTRIES ${ }^{(*)}$

Pablo Burriel and Alessandro Galesi

BANCO DE ESPAÑA

$\left.{ }^{*}\right)$ A previous version of this paper circulated under the title "Unconventional monetary policies in the euro area: a global VAR analysis». We would like to thank Martin Feldkircher, Omar Rachedi, and conference and seminar participants at Banco de España, Central Bank of Ireland, XIX Applied Economics Meeting, II Workshop ANAECO, 6th IWH/INFER Workshop on (Ending) Unconventional Monetary Policy, and members of the ECB Expert Group on the Inclusion of Non-Standard Measures for helpful comments and suggestions. Disclaimer: The views expressed herein are those of the authors and not necessarily those of Banco de España or the Eurosystem. E-mail: pburriel@bde.es (Burriel), alessandro.galesi@bde.es (Galesi). 
The Working Paper Series seeks to disseminate original research in economics and finance. All papers have been anonymously refereed. By publishing these papers, the Banco de España aims to contribute to economic analysis and, in particular, to knowledge of the Spanish economy and its international environment.

The opinions and analyses in the Working Paper Series are the responsibility of the authors and, therefore, do not necessarily coincide with those of the Banco de España or the Eurosystem.

The Banco de España disseminates its main reports and most of its publications via the Internet at the following website: http://www.bde.es.

Reproduction for educational and non-commercial purposes is permitted provided that the source is acknowledged.

C BANCO DE ESPAÑA, Madrid, 2016

ISSN: 1579-8666 (on line) 


\section{Abstract}

We assess the effects of the ECB's recent unconventional monetary policy measures by estimating a global VAR that exploits panel variation among all euro area economies and explicitly takes into account cross-country interdependencies. Unconventional monetary policy measures have beneficial effects on activity, credit, inflation and equity prices, and lead to a depreciation of the exchange rate. Most euro area members benefit from these measures, but with a substantial degree of heterogeneity. Cross-country spillovers account for a sizable fraction of such dispersion, and substantially amplify effects. Countries with less fragile banking systems benefit the most from unconventional monetary policy measures. Compared to expansionary conventional monetary policies, unconventional measures are particularly effective in reducing firms' financing costs and boosting credit.

Keywords: unconventional monetary policy, euro area, GVAR, heterogeneity, spillovers.

JEL classification: C32, E52, E58. 


\section{Resumen}

En este docuemento se evalúa el efecto de las medidas no convencionales de política monetaria adoptadas recientemente por el BCE por medio de un modelo VAR Global que explota la variación existente entre las variables de las economías que conforman el área del euro y tiene en cuenta de forma explícita las interdependencias entre países. La estimación del modelo muestra que las medidas de política monetaria no convencional tienen efectos positivos sobre la actividad, el crédito, la inflación y el precio de los activos, y producen una depreciación del tipo de cambio. La mayoría de los países miembros se benefician de estas medidas, pero existe un elevado grado de heterogeneidad. Una parte muy significativa de esta heterogeneidad se explica por las interacciones entre las economías del área del euro, recogidas explícitamente en nuestro modelo, que a su vez amplifican sustancialmente los efectos estimados. Si se compara con la política monetaria convencional (expansiva), las medidas de carácter no convencional parecen ser más efectivas en la coyuntura actual para reducir el coste de financiación de las empresas y potenciar el crédito.

Palabras clave: política monetaria no convencional, área del euro, GVAR, heterogeneidad, spillovers.

Códigos JEL: C32, E52, E58. 


\section{Introduction}

The events since the collapse of Lehman Brothers in September 2008 led central banks around the world to employ unconventional monetary policy (UMP) measures to fulfill their mandate of price stability. In the case of the ECB, the monetary policy response to the crisis has been shaped by the particularly large degree of heterogeneity across euro area members. In this vein, ECB President Mario Draghi stated:

"We faced severe impairments to the transmission of monetary policy across the euro area, with marked heterogeneity from country to country. This called for unconventional measures tailored to the specific frictions at hand." Draghi (2014)

Besides country heterogeneities, also interactions among members of the euro area play an important role on determining the effectiveness of UMP measures through spillover effects. In this respect, President Draghi also observed that:

"Today's economic and monetary union is larger and more diverse than a single country, such as Germany. It is highly integrated but still at times fragmented. And it comprises a very large number of policy-makers on fiscal, structural and other economic matters.

All policy-makers have to recognise that we belong to EMU together and that policies as well as policy inaction create spillovers for other members. This is an enormous responsibility for governments and other economic policymakers." Draghi (2013)

These remarks suggest that the assessment of the effectiveness of recent ECB's UMP measures requires dealing with heterogeneities and interdepencies across members of the euro area. In this paper we shed light on these issues by estimating a global VAR (GVAR), a multi-country model which exploits panel variation amongst all current members of the monetary union. The model is composed by two blocks: a system of national VAR models in which cross-country interactions are explicitly taken into account, and a VAR model for 
the common monetary policy. Two features of this framework are particularly attractive. First, being a multi-country model, the GVAR deals with country heterogeneities and allows for an assessment of asymmetries in the transmission of UMP measures. And second, the model allows monetary policy to affect a given economy not just directly, but also indirectly via cross-country interactions. Hence by taking into account spillovers across members of the euro area, the GVAR allows for a better identification of the impact of UMP shocks.

We estimate our model over the period January 2007 - September 2015, and study the effects of UMP shocks both for the whole euro area and for all member countries. Unconventional monetary policies have beneficial effects on aggregate output and inflation, confirming their role as a stabilization tool. UMP shocks also increase credit, equity prices, and lead to a depreciation of the exchange rate. At the disaggregated level, UMP shocks benefit most of the euro area members, with substantial degree of heterogeneity. Spillover effects account for a sizable fraction of such dispersion, and substantially amplify the effects of UMP shocks. Countries with less fragile banking systems benefit the most from unconventional monetary policies, both in terms of direct and spillover effects. When comparing the effects of UMP shocks with those arising from standard conventional monetary policies, we find that unconventional measures are particularly effective in reducing firms' financing costs and boosting credit. We read this evidence as suggesting that the ECB's unconventional monetary policies, thanks to its more targeted nature, have been particularly effective at reducing financial fragmentation and thus expanding credit.

This paper links to the recent strand of the literature dealing with the quantification of the macroeconomic effects of unconventional monetary policy in the euro area. Giannone et al. (2011) and Gambacorta et al. (2014) show that recent UMP measures have positive and significant effects on output of the eurozone. ${ }^{1}$ Boeckx et al. (2014) also show that most of the euro area countries benefit from UMP measures, and docu-

\footnotetext{
${ }^{1}$ Several papers have alternatively analyzed the effects of UMP measures undertaken by central banks in other advanced economies: for instance, Krishnamurthy and Vissing-Jorgensen (2013) and Feldkircher and Huber (2016b) for the US, Kapetanios et al. (2012) for the UK, Schenkelberg and Watzka (2013) for Japan, while Baumeister and Benati (2013) compare the effects of policies by the US Federal Reserve and the Bank of England.
} 
ment that countries with less capitalized banks feature lower output effects. In our paper we borrow from Boeckx et al. (2014) the identification strategy of UMP disturbances, which relies on extracting the exogenous innovations to the ECB's balance sheet using zero and sign restrictions. However we depart in at least one important dimension: while the authors employ independent country-specific Structural VAR models, we consider a multi-country framework in which cross-country interactions are explicitly modeled. We show that accounting for spillover effects is crucial for a proper quantification of the size and dispersion of the effects of UMP shocks.

Our paper also relates to the literature studying heterogeneities in the transmission of ECB's monetary policy. In this respect, Ciccarelli et al. (2013) show that the impact of conventional monetary policies on aggregate output was stronger during the financial crisis, especially in countries facing increased sovereign financial distress. More recently, Georgiadis (2015b) shows that the transmission of conventional monetary policy shocks across economies of the euro area displays asymmetries which are driven by a number of key country-specific structural characteristics. The author proposes a mixed cross section GVAR model which allows to capture the endogenous two-way feedback loops between the common monetary policy of the ECB and euro area economies. In this vein, we follow the methodology of Georgiadis (2015b) to study heterogeneities in the transmission of unconventional monetary policies across members of the euro area.

And finally, our paper links to the literature on the international transmission of monetary policy shocks. In this respect, two recent papers analyze the international spillovers stemming from US conventional monetary policies: Georgiadis (2015a) provides evidence that spillovers are generally large, and often larger than domestic effects; Feldkircher and Huber (2016a) also estimate sizable spillovers, which internationally transmit through interest rate and exchange rate. Similarly to these studies we employ the GVAR methodology, but here we focus on analyzing spillover effects of UMP shocks across euro area economies. In this respect, our paper links to Bluwstein and Canova (2016), which study the effects of UMP measures of the European Central Bank on a set of European countries not adopting the euro, and find that spillovers are larger in countries with more advanced financial systems and a larger share of domestic banks. 
The structure of the paper is as follows. Section 2 describes the empirical analysis: the GVAR model, the data and the specification of the model, the identification strategy, and the estimation. Section 3 presents the results of the analysis. Section 4 discusses robustness checks. Section 5 concludes.

\section{The Empirical Analysis}

\subsection{The GVAR Model}

The analysis is based on a GVAR modeling framework as firstly developed in Pesaran et al. (2004) and extended in Dees et al. (2007). We explicitly model each member economy of the euro area in the spirit of the mixed cross section GVAR developed in Georgiadis (2015b). The model consists of two blocks: $(i)$ a system of 19 national VAR models in which cross-country interactions are explicitly modeled; (ii) a VAR model for common factors which affect all euro area countries, for instance the ECB's monetary policy. Figure 1 depicts a stylized graph of the structure of the model. Monetary policy shocks affect a given economy not just directly, but also indirectly via cross-country interactions. Moreover, the common monetary policy depends on economic developments at the euro area level, hence the model allows to capture the endogenous two-way feedback loops between countries and the common monetary policy of the ECB.

Each national economy $i$ is modeled as a $\operatorname{VARX}\left(p_{i}, q_{i}\right)$,

$$
Y_{i, t}=c_{i}+\sum_{j=1}^{p_{i}} A_{i j} Y_{i, t-j}+\sum_{j=0}^{q_{i}} B_{i j} Y_{i, t-j}^{*}+\sum_{j=0}^{q_{i}} C_{i j} X_{t-j}+u_{i t}
$$

where $u_{i t}$ is a vector of reduced form residuals; $c_{i}$ is a vector of intercepts; $A_{i j}, B_{i j}$, and $C_{i j}$ are matrices of coefficients. The vector $Y_{i t}$ includes domestic variables which represent the domestic macroeconomic and financial conditions of the economy. The vector $Y_{i t}^{*}$ contains foreign-specific variables, which represent the influence of the main economic partners of a given economy and capture the relative spillovers. These variables are calculated as weighted averages of the corresponding domestic variables of other countries, with weights based on bilateral trade flows. Specifically, the $Y_{i, t}^{*}$ variables are constructed as

$$
Y_{i, t}^{*}=\sum_{j=1}^{N} w_{i, j} Y_{j, t} \quad \text { with } \quad w_{i, i}=0 \quad \forall i=1, \ldots, N, \quad \sum_{j=1}^{N} \tilde{w}_{i, j}=1
$$


Figure 1: Structure of the GVAR

System of 19 inter-linked national VARs

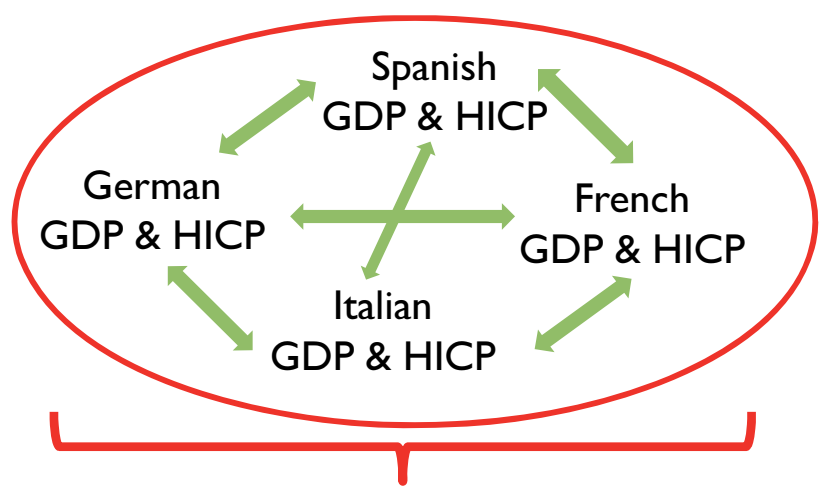

euro area GDP \& HICP
VAR model for common factors

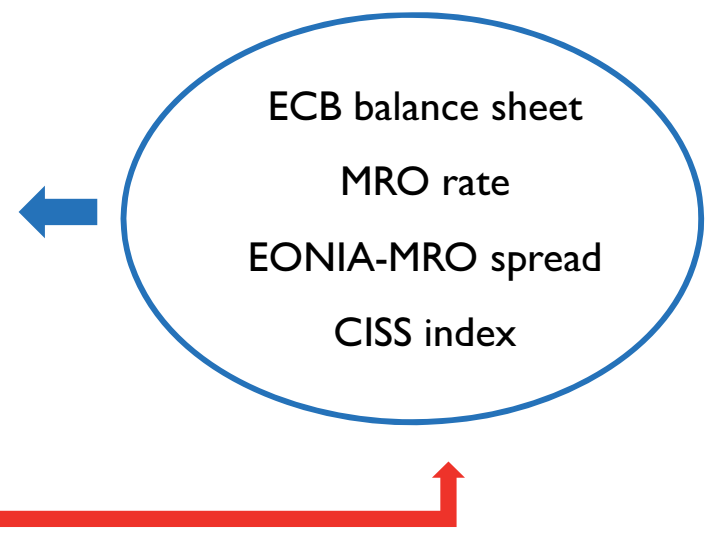

Notes: the graph shows the structure of the model in a simplified setting with four countries and two country-specific variables given by GDP and HICP. In practice, the model includes all current members of the euro area and a larger set of country-specific variables.

The vector $X_{t}$ includes common variables, such as monetary policy, which enter in each country-specific model. Common variables follow the process

$$
X_{t}=c_{x}+\sum_{j=1}^{p_{x}} D_{j} X_{t-j}+\sum_{j=1}^{q_{x}} F_{j} \tilde{Y}_{t}+u_{x, t}
$$

where $u_{x t}$ is a vector of reduced form residuals; $c_{x}$ is a vector of intercepts; $D_{j}$ and $F_{j}$ are matrices of coefficients. The vector $\tilde{Y}_{t}$ is composed by weighted averages of all countries' domestic variables, where weights are based on GDP shares, and capture the effects of macroeconomic developments at the euro area level on the common factors. In order to identify such effects, we assume that $\tilde{Y}_{t}$ enters in the model with a lag. Intuitively, this amounts to assume that the monetary authority observes today the state of the economy at the euro area level, and decides monetary policy measures which will take place the subsequent month.

Foreign-specific variables are linear combinations of the endogenous variables, $Y_{i, t}^{*}=$ $W_{i} Y_{t}$, where $W_{i}$ are country-specific matrices defined by the trade weights. Hence we can write each country-specific model as

$$
G_{i 0} Y_{i, t}=c_{i}+\sum_{j=1}^{p_{i}} G_{i j} Y_{i, t-j}+\sum_{j=0}^{q_{i}} C_{i j} X_{t-j}+u_{i t}
$$


where $G_{i 0}=\left(I-B_{i 0} W_{i}\right)$ and $G_{i j}=\left(A_{i j}+B_{i j} W_{i}\right)$. We can then stack all country-specific models to obtain

$$
G_{0} Y_{t}=c+\sum_{j=1}^{p} G_{j} Y_{t-j}+\sum_{j=0}^{q} C_{j} X_{t-j}+u_{t}
$$

where $Y_{t}=\left(Y_{1, t}^{\prime}, \ldots, Y_{N, t}^{\prime}\right)^{\prime}, G_{0}=\left(G_{10}^{\prime}, \ldots, G_{N 0}^{\prime}\right)^{\prime}, c=\left(c_{1}^{\prime}, \ldots, c_{N}^{\prime}\right)^{\prime}, G_{j}=\left(G_{1 j}^{\prime}, \ldots, G_{N j}^{\prime}\right)^{\prime}$, $C_{j}=\left(C_{1 j}^{\prime}, \ldots, C_{N j}^{\prime}\right)^{\prime}, p=\max \left(p_{i}\right)$, and $q=\max \left(q_{i}\right)$.

Moreover, we can exploit the fact that euro area variables are weighed averages of country-specific variables, $\tilde{Y}_{t}=\tilde{W} Y_{t}$, where $\tilde{W}$ is a matrix based on GDP weights, to combine the two blocks of the global VAR model, in order to obtain

$$
H_{0} Z_{t}=h_{0}+\sum_{j=1}^{p} H_{j} Z_{t-j}+\tilde{u}_{t}
$$

where the vector $Z_{t}=\left(Y_{t}^{\prime}, X_{t}^{\prime}\right)^{\prime}$ which includes all country-specific and common variables, and

$$
H_{0}=\left[\begin{array}{cc}
G_{0} & -C_{0} \\
0 & I
\end{array}\right], \quad h_{0}=\left[\begin{array}{c}
c \\
c_{x}
\end{array}\right], \quad H_{j}=\left[\begin{array}{cc}
G_{j} & C_{j} \\
F_{j} \tilde{W} & D_{j}
\end{array}\right], \quad \tilde{u}_{t}=\left[\begin{array}{c}
u_{t} \\
u_{x, t}
\end{array}\right] .
$$

Provided that the $H_{0}$ matrix is invertible, we can obtain the $\operatorname{GVAR}(p)$ in its reduced form,

$$
Z_{t}=\tilde{h}_{0}+\sum_{j=1}^{p} \tilde{H}_{j} Z_{t-j}+v_{t}
$$

where $\tilde{h}_{0}=H_{0}^{-1} h_{0}, \tilde{H}_{j}=H_{0}^{-1} H_{j}$, and $v_{t}=H_{0}^{-1} \tilde{u}_{t}$ are reduced form shocks $v_{t}$ with zero mean and full variance-covariance matrix $\Sigma$.

The dynamic properties of the global model are now determined by the $Z_{t}$ process, including impulse response functions. In this respect, we can express the reduced form shocks as a linear combination of structural shocks $\varepsilon_{t}$ so that $V \varepsilon_{t}=v_{t}$, where structural shocks are normalized to have unit variance $I=E\left(\varepsilon_{t} \varepsilon_{t}^{\prime}\right)$. This implies the restriction that $V V^{\prime}=\Sigma$. In practice, we are interested in identifying two specific columns of $V$ which characterize the impact effects of unexpected unconventional and conventional monetary policy shocks. To do so, we employ a combination of sign and zero restrictions as discussed in section 2.3 . 


\subsection{Data and specification of the model}

The data used in the analysis have monthly frequency over the period January 2007 - September 2015. During this period the ECB has intensively employed non-standard monetary policy measures, which justifies our choice of the sample period. In this respect, many authors have emphasized that the use of data prior to the financial crisis may not be adequate to assess the effects of the recently adopted unconventional monetary policy measures, see for instance Lenza et al. (2010) and Boeckx et al. (2014).

With regards to the common variables in $X_{t}$, we follow Boeckx et al. (2014) and consider the ECB's balance sheet as our key indicator of unconventional monetary policy. Specifically, we use the year-on-year rate of growth of ECB's total assets. We also include a measure of financial stress and economic risk at the eurozone level, proxied by the CISS indicator of Holló et al. (2012). There are a number of reasons why we include a measure of financial distress at the euro area level. First, the strong and positive correlation between the rate of growth of ECB's assets and the CISS index suggests that a large component of the central bank's balance sheet is endogenous. To disentangle exogenous disturbances and endogenous responses of ECB's balance sheet, we impose sign restrictions on responses of financial distress as in Boeckx et al. (2014). Secondly, the CISS index may capture relevant effects of international factors which strike the eurozone as a whole, such as global uncertainty or developments in commodity markets. In this respect, Kremer (2016) includes the CISS index in an otherwise standard macro-financial SVAR model and documents the important role of financial distress for the euro area.

Among the common variables we also include the interest rate on Marginal Refinancing Operations (MRO) to proxy for conventional monetary policy. Over the course of the recent eurozone's crisis, the ECB responded with a diversified package of non-standard measures, while at the same time conventional monetary policy was exhausting its scope as the MRO rate gradually approached its zero lower bound. There is evidence that, while being operative, the interest rate instrument has been effective in avoiding a more severe recession. For instance, Ciccarelli et al. (2013) document that the impact of conventional monetary policy on aggregate output has been stronger during the financial 
crisis, especially in countries facing increased sovereign financial distress. Finally, we include a measure of interbank market's liquidity, proxied by the spread between the EONIA and the MRO rate, and 5-years-on-5-years inflation swaps developed in Gimeno and Ortega (2015) as a proxy for inflation expectations at the euro area level.

We focus our analysis on the 19 euro area member economies, and for each economy we use data on macroeconomic and financial indicators. To account for the macroeconomic conditions we include output and prices, which are proxied by the yearly rate of growth of real GDP and of the Harmonized Index of Consumer Prices (HICP). Since GDP is at quarterly frequency, we construct a monthly measure of real GDP using the Chow-Lin interpolation procedure where monthly industrial production and the volume of sales in wholesale and retail trade are the reference series.

In addition, we include other domestic variables to capture those relevant channels of transmission of unconventional monetary policies that are not properly captured by aggregate variables due to financial fragmentation. In particular, from the financial side, we consider the yearly change of real equity prices to account for a portfolio rebalancing channel. We also include the yearly change in the volume of new bank lending operations to non-financial corporations, and a measure of cost of borrowing for firms as developed in Gilchrist and Mojon (2014), to account for a credit channel. Finally, we also include the real effective exchange rate. All nominal variables are deflated by the domestic HICP. Due to data limitations, some country-specific models do not include all indicators.

In order to capture potential spillovers across countries, we consider country-specific weighted averages of trade partners' real GDP growth. Weights are computed using crosscountry bilateral trade flows, where data come from the World Input Output Database (WIOD). Turning to the feedback variables $\tilde{Y}_{t}$, we include weighed averages of all countryspecific variables, where weights are based on shares of real GDP in the eurozone. Finally, we use the same GDP weights for aggregating country-specific impulse responses at the euro area level. Table A.1 summarizes the variables employed in the GVAR and data sources, while Table A.2 reports the specification of each country model. 


\subsection{Identification}

The fact that during our sample the ECB has undertaken a large variety of unconventional monetary measures means that its balance sheet may not be a perfect indicator for each of them, but it is probably the closest proxy to a policy instrument that one can find. In order to disentangle exogenous movements from endogenous reactions of the ECB's balance sheet, we borrow the identification strategy of Boeckx et al. (2014), which use a combination of zero and sign restrictions on impulse responses. In particular, we identify exogenous balance sheet shocks by requiring that an expansion of the balance sheet (1) reduces the EONIA-MRO spread and (2) does not increase financial distress, measured by CISS. Table 1 summarizes the identification strategy.

Table 1: Identification of monetary policy shocks

\begin{tabular}{lccccccc}
\hline \hline & $\begin{array}{c}\text { ECB total } \\
\text { assets }\end{array}$ & $\begin{array}{c}\text { MRO } \\
\text { rate }\end{array}$ & $\begin{array}{c}\text { EONIA- } \\
\text { MRO spread }\end{array}$ & $\begin{array}{c}\text { CISS } \\
\text { index }\end{array}$ & $\begin{array}{c}\text { Real GDP } \\
\text { growth }\end{array}$ & $\begin{array}{c}\text { HICP } \\
\text { inflation }\end{array}$ & $\begin{array}{c}\text { New credit } \\
\text { growth }\end{array}$ \\
\hline \multirow{2}{*}{ Balance sheet shock } & $\geq$ & 0 & $\leq$ & $\leq$ & 0 & 0 & 0 \\
Interest rate shock & 0 & $\leq$ & $?$ & $?$ & $\geq$ & $\geq$ & 0 \\
\hline \hline
\end{tabular}

Notes: $\geq$ indicates that response is restricted to be non-negative, $\leq$ to be non-positive, ? is left unrestricted, 0 to be zero on impact (and unrestricted afterwards). Sign restrictions are imposed on impact and up to three months after the shock. Zero restrictions are imposed on impact only. Responses of inflation expectations, equity prices, cost of debt, and real effective exchange rate are left unrestricted.

Restriction (1) captures the fact that exogenous expansions of the ECB balance sheet, by increasing the liquidity surplus, are effective in reducing the EONIA and its spread with the policy rate. This fact is documented on a number of recent studies. For instance, Lenza et al. (2010) have shown that measures undertaken by the ECB in the aftermath of the crisis had sizeable effect in compressing spreads on loans and interest rates. Abbassi and Linzert (2012) find that non-standard monetary policy measures as of October 2008 helped to lower Euribor rates by more than 80 basis points. Beirne et al. (2011) analyze the effects of the covered bond purchase programme (CBPP) on both the primary and secondary bond markets and find that it has contributed to a decline in money market term rates and to improve market liquidity in important segments of the private debt securities market. 
By postulating restriction (2) we are disentangling exogenous shocks to the ECB's balance sheet from endogenous expansions. The expected endogenous expansion which we rule out arises when for instance higher financial distress induces banks to increase their demand for liquidity, which gets satisfied by the Fixed Interest Rate with Full Allotment (FRFA) policy implemented by the ECB very early on during the crisis.

Sign restrictions are imposed on impact and up to three months after the shock. We also assume that balance sheet shocks have a lagged impact on the real economy, by imposing zero impact effects on impact on output and prices. The rationale is that the monetary authority observes today's output and prices when deciding its policy measures, so that these variables do not react contemporaneously to the monetary policy surprise. This assumption has been extensively used in the literature (e.g. Peersman and Smets, 2003; Ciccarelli et al. 2013). We also impose a zero restriction on impact on credit, to capture its sluggish nature. And finally, to distinguish balance sheet movements from standard conventional monetary policy, we impose a zero restriction on impact on the MRO rate. The impulse responses of the remaining variables are left unrestricted.

In addition, we identify a standard conventional monetary policy shock by means of zero and sign restrictions. Specifically, we require that a lowering of the MRO policy rate increases output and inflation of the euro area. In practice, we do not impose that output and inflation increase in all euro area member economies, just that the average response across countries is positive, weighted by real GDP shares. These restrictions are imposed from one up to three months after shock, while there is a zero restriction on impact, to be consistent with the identification of the UMP shock. Following the same rationale, we impose a zero restriction on impact for the impulse response of credit. Finally, to disentangle conventional and unconventional monetary policy shocks, we require that the balance sheet does not react on impact. As for the UMP shock, impulse responses of the remaining variables are left unrestricted.

Importantly, by requiring a positive response of activity and prices to an exogenous reduction of the policy rate, we are implicitly imposing the effectiveness of conventional monetary policy shocks. This assumption is not necessarily agnostic, as it has been 
recently advocated in Arias et al. (2015). Conversely, we are agnostic about whether exogenous balance sheet shocks are effective in boosting activity and prices, which is one of the key questions we address in this paper.

The implementation of the sign restrictions is based on the algorithm developed in Arias et al. (2014). In practice, we draw 5000 matrix rotations for each of the 2000 bootstrap replications of the GVAR. This relatively high number of draws allows for obtaining a sufficient number of accepted draws for confidence intervals. ${ }^{2}$ Moreover, robustness checks on the identification strategy are reported in section 4.

\subsection{Estimation}

Due to the large amount of coefficients of the GVAR, the direct estimation of equation (7) is practically unfeasible with standard techniques. To overcome the curse of dimensionality, the idea is to conduct the estimation of the model on a country-by-country basis. First, we estimate each country-specific model under the assumption that foreign-specific and common factors are weakly exogenous. Then, we estimate the model for the common factors, taking into account that the feedback variables $\tilde{Y}_{t}$ are predetermined as they enter with a lag.

For each country-specific model we choose a relatively parsimonious lag structure by setting the lag order of the endogenous variables, $p_{i}$, equal to two. The lag order of foreign-specific and common variable, $q_{i}$, is set equal to zero, which implies that exogenous variables enter just contemporaneously in each country model. This assumption mimics the structure of widely-used dynamic factor models in which unobserved common factors affect just contemporaneously the idiosyncratic variables. With respect to the model for the common factors, we fix the lag order of the endogenous variables $p_{x}$ equal to two, and we set the lag order of the feedback variables $q_{x}$ equal to two.

In principle, such parsimonious structure of lag orders may not adequately capture the serial correlation of the modeled variables. However the GVAR model, due to its high cross-sectional dimension, may allow for very complex univariate dynamics. The idea

\footnotetext{
${ }^{2}$ We have also experimented identifying just the UMP shock, by using either 500 or 5000 matrix rotations for each bootstrap replication, and results are virtually identical.
} 
is that a $N$-dimensional $\operatorname{VAR}(1)$ process admits an $\operatorname{ARMA}(N, N-1)$ representation of each univariate, provided no root cancelations occur (see for instance Harvey, 1990). Our GVAR combines $N=88$ processes, it has lag order equal to two, hence it may adequately account for very articulated processes. To verify that this is the case, Figures A.2 and A.3 report the sample autocorrelation functions of the GVAR residuals. Most of residuals are serially uncorrelated, which confirms that the model captures most of the persistence of the data.

\section{Results}

In this section we first present the effects of unconventional monetary policy shocks at the euro area level, focussing on the key transmission channels. Then we focus on the effects at the country level, to study the degree of heterogeneity in responses and its potential determinants. To dig further on this issue, we compare the country-specific effects produced by UMP shocks with those obtained by conventional monetary policy surprises.

\subsection{Aggregate effects and transmission channels of UMP shocks}

We first present the effects of unconventional monetary policy shocks for the aggregate of the euro area. To do so, we aggregate the country-specific impulse responses (medians, 16th and 84th percentiles) using GDP shares. Figure 2 plots the impulse responses to an exogenous, one percent increase, in the rate of growth of total ECB assets, where solid lines represent median estimates while the areas cover the 16 th -84 th percentiles. The UMP shock leads to a persistent increase in total assets which fades out after two years. Given the imposed sign restrictions, both the EONIA-MRO spread and the CISS index fall. The response of the policy rate is not significant at any horizon, hence it confirms that the UMP shock does not imply a reaction of conventional monetary policy. 
Figure 2: Euro area wide responses to an unconventional monetary policy shock
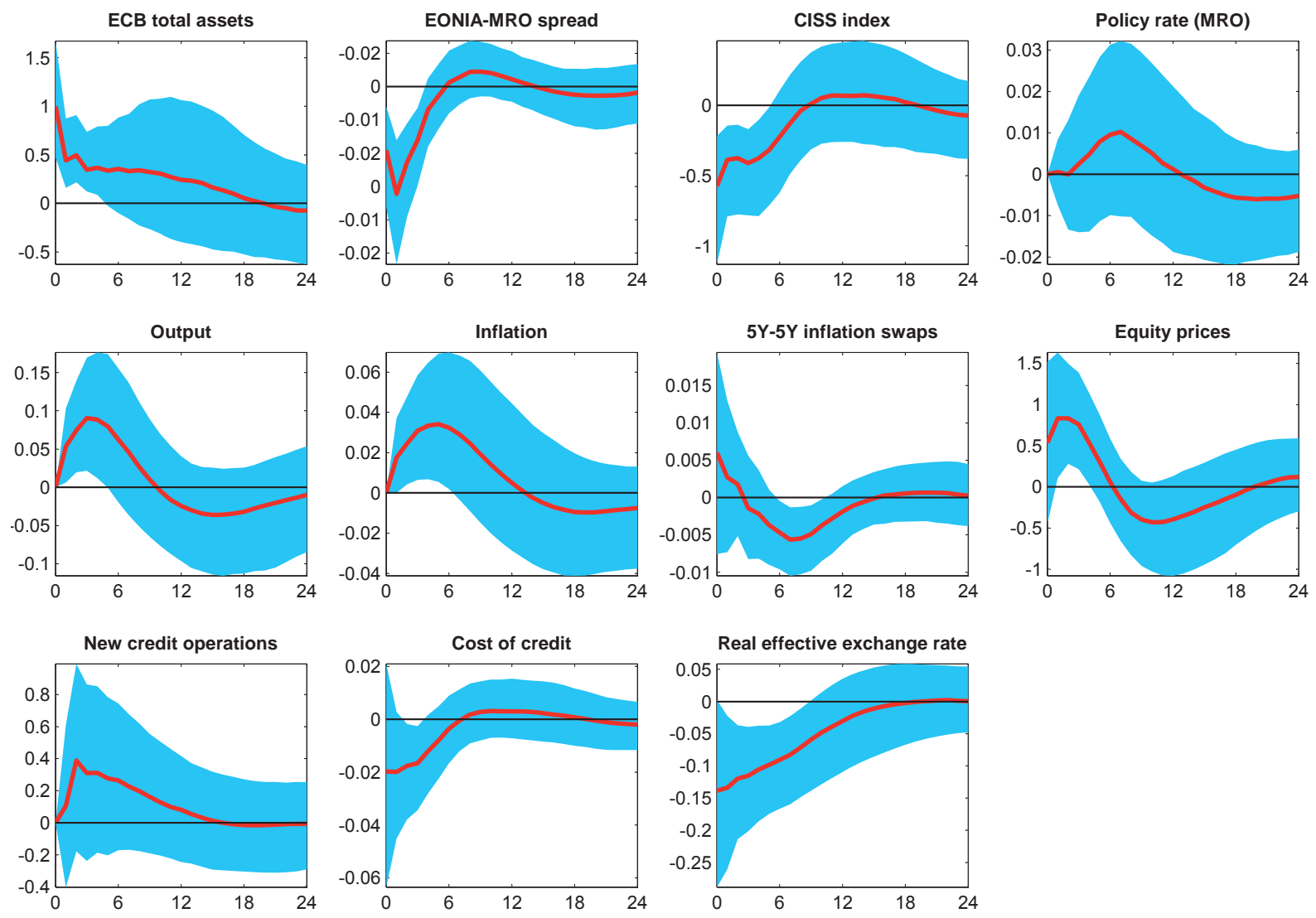

Notes: responses to a one percent increase in growth of ECB assets. Solid red lines represent the median estimates and blue areas denote the 16 th and 84 th percentiles.

Output growth and inflation significantly increase, with peak effects of about $0.08 \%$ and $0.03 \%$, respectively. Dynamic responses are hump-shaped and fade out after roughly 6 months, in line with the literature (e.g. Boeckx et al., 2014). Despite a significant increase in inflation, inflation expectations do not significantly react to the UMP shock, and therefore suggest that the data cannot uncover a signaling channel at work. This result is consistent with van den End and Pattipeilohy (2015), which show that shocks to the size or composition of the ECB's balance sheet have no substantial effects on long-term inflation expectations. Potentially, inflation expectations at the short-term may better capture reactions to UMP shocks. We rule out this explanation in section 4.3, where we employ data on inflation expectations at either 2-years-on-2-years or 1-year-on-1-year, and show that responses of inflation expectations are, albeit positive, still not significant. 
Alternatively, if market agents rapidly internalize the expected effects of UMP announcements, most of the variation in measured expectations should occur around ECB's announcements. In this respect, the ECB's balance sheet, which captures the actual undertaking of programs rather than the announcements, may not allow to precisely identify the reaction of inflation expectations. In section 4.4 we explore this possibility using a measure of shadow interest rate developed in Wu and Xia (2016) as alternative unconventional monetary policy indicator. Despite this measure should account for announcement effects, results show that inflation expectations do not significantly react to UMP shocks.

Real equity prices significantly increase, with a peak of about $0.8 \%$ after one month, and the response fades away after few months. This evidence provides support to a portfolio rebalancing channel. Moreover, results suggest that also the channel of the exchange rate is at work. The real effective exchange rate strongly depreciates, as the impulse response falls by about $0.12 \%$ and fades away in less than one year. This result is in line with findings in van den End and Pattipeilohy (2015), in which an expansion of the central bank's balance sheet is associated with a depreciation of the euro.

Finally, the responses related to the credit indicators have the expected signs, since new credit operations increase while at the same time the cost of credit falls. This result suggests that credit is a relevant transmission channel of UMP. However, the effects are barely significant for the cost of credit and not significant for the new credit operations. A possible reason is that there is a large degree of heterogeneity across country responses which is masked by aggregating country-specific effects. In the next section we show that indeed there exist a large dispersion of effects and investigate its sources.

\subsection{Heterogeneous effects of UMP shocks}

We now present the effects of UMP shocks at the country level. Figure 3 provides a preliminary sense of the extent of heterogeneity in effects across countries, by plotting the median peak responses of inflation and output growth to the common UMP shock, grouped by interquartile ranges. Figure A.1 plots the same statistics, joint with the relative one-standard-error bands. We point out two results. The effects of UMP shocks are positive and statistically significant in most euro area countries. Second, there are 
important heterogeneities in terms of magnitudes of effects, despite the substantial uncertainty of estimates. With respect to effects on inflation, Estonia features the highest increase (about 0.10\%), followed by Latvia, Luxembourg, and Spain (about 0.06\%). Conversely, the smallest effects are observed in France, Germany, and Italy (about 0.03\%), and Cyprus, for which the effect is not significantly different from zero. Regarding the effects on output growth, Baltic countries feature the highest increases, while interestingly, effects are negligible in Spain, or not statistically significant in Portugal and Greece.

Figure 3: Geographic variation of responses to UMP shocks

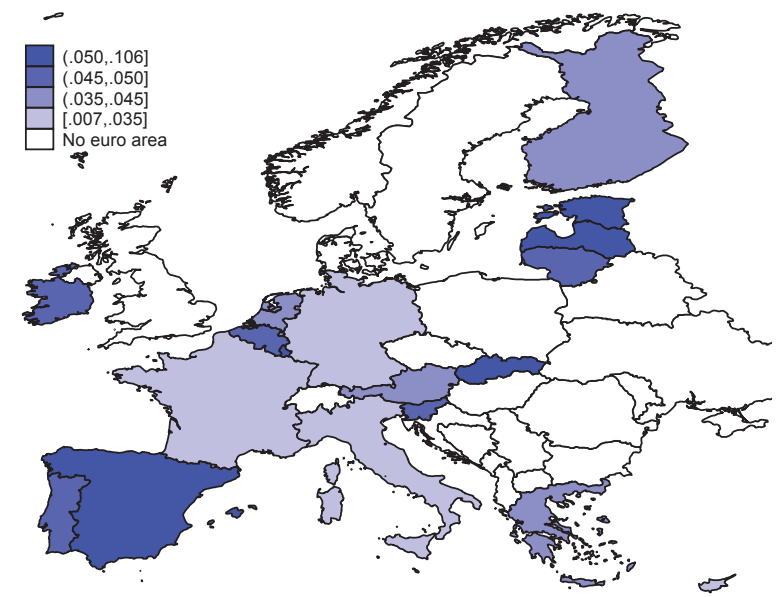

(a) Inflation

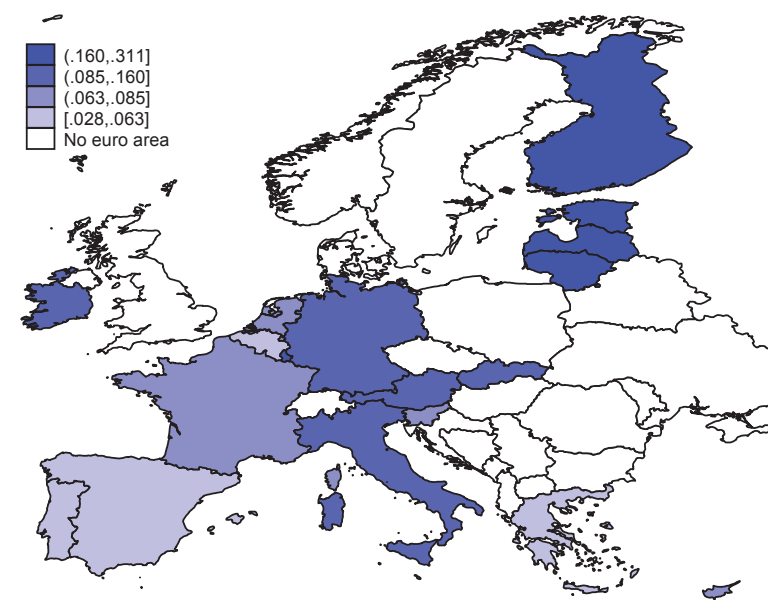

(b) Output growth

Notes: maps display the median peak responses of HICP inflation and real GDP growth to a one percent increase in central bank's total assets growth.

One interesting question is to assess the role of cross-country interactions in determining the impact of of unconventional monetary policies via spillover effects. To this end, we compare the effects of UMP shocks with those arising from a model in which crosscountry linkages are not taken into account. While the identification strategy of the UMP shocks remains the same, we consider an alternative version of the country-specific models in (1) which omits the set of foreign-specific variables $Y_{i}^{*}$. In this way, cross-country linkages and resulting spillover effects get neglected. Specifically, every country model is now expressed as

$$
Y_{i, t}=\tilde{c}_{i}+\sum_{j=1}^{p_{i}} \tilde{A}_{i j} Y_{i, t-j}+\sum_{j=0}^{q_{i}} \tilde{C}_{i j} X_{t-j}+\tilde{u}_{i t}
$$


In this alternative model, UMP shocks affect a specific country $i$ through their direct effect coming from the vector of common factors $X_{t}$, but any effect from other countries $j \neq i$ is absent. As in the benchmark model, we assume that the process for the common factors is defined by equation (3). We can then decompose the originally estimated impacts into two components: $(i)$ direct effects, which are estimated from the model without linkages; and (ii) spillovers, which are the difference between the effects obtained from the benchmark model and those arising from the model without linkages.

Figure 4 plots the median peak responses of output growth and inflation to a one percent UMP shock, decomposed into direct effects (dark blue bars) and spillovers (light blue bars). We point out two results. First, spillover effects dramatically amplify the effects of UMP shocks. Without spillovers, the (unweighed) average peak response of output growth is about $0.06 \%$, while the effect is doubled $(0.12 \%)$ when accounting for spillovers. Similarly, the average peak responses of inflation are about $0.03 \%$ and $0.05 \%$, respectively without and with spillovers. Second, a substantial part of the heterogeneity in effects is due to spillover effects. In absence of cross-country interactions, effects on output growth range in between $0.02 \%$ and $0.12 \%$, while effects on inflation lie in between zero and $0.07 \%$. When spillover effects are taken into account, the range of responses of output growth significantly increases $(0.03 \%-0.31 \%)$, as well as the range of responses of inflation $(0.01 \%-0.11 \%)$.

To sum up, most euro area members benefit from UMP shocks, with a significant degree of heterogeneity. A substantial component of the effects is attributable to crosscountry interactions and the resulting spillovers. One take-away from this analysis is that it is crucial to account for cross-country interdependencies and spillovers when assessing the effectiveness of monetary policy across euro area countries. By neglecting crosscountry interactions, the model substantially underestimates the effects of UMP shocks. Importantly, the model does not capture spillover and spillback effects between the euro area and the rest of the world. As shown in Georgiadis (2015c), abstracting from such higher-order transmission channels may lead to underestimate spillovers. In this vein, our spillover estimates are conservative, in the sense that the relevance of spillovers could be amplified when accounting for interactions with the rest of the world. 
Figure 4: Direct and spillover effects of UMP shocks

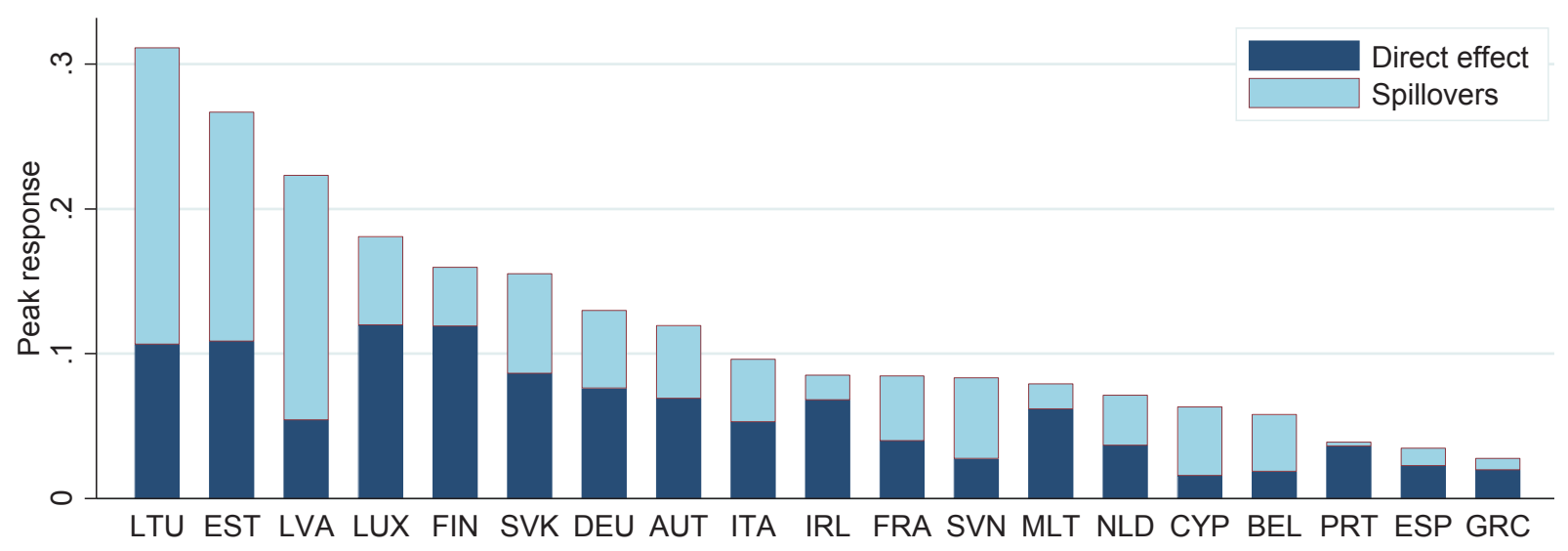

(a) Output growth

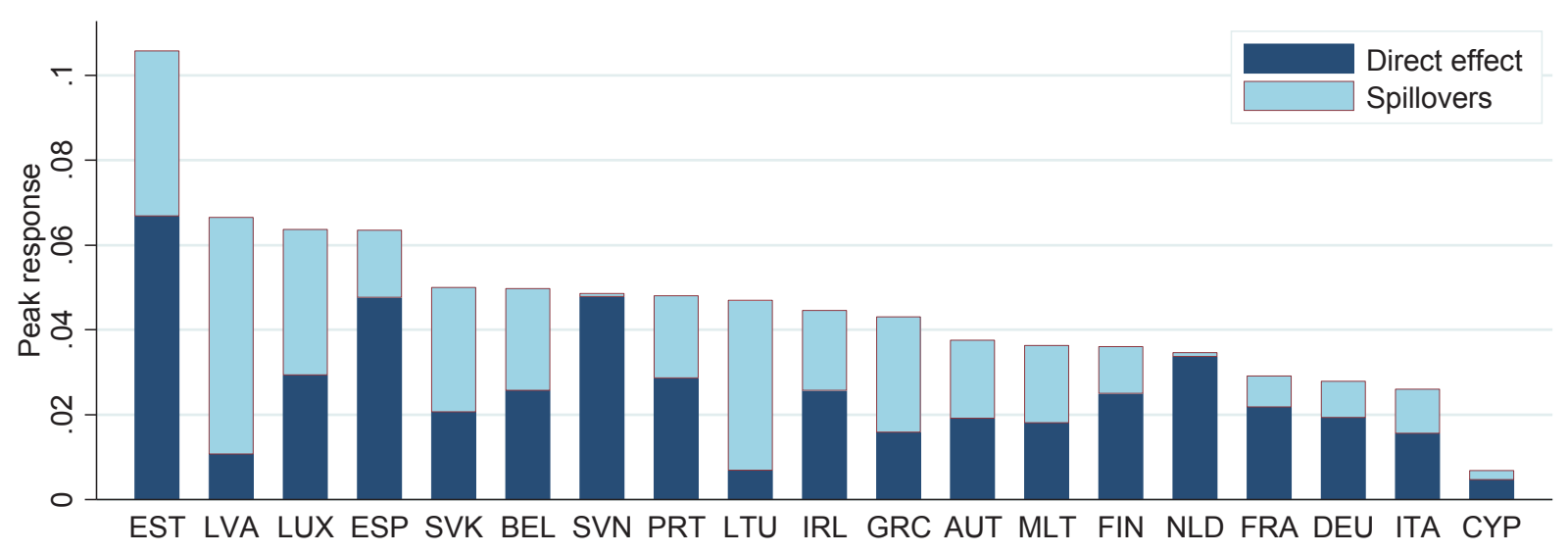

(b) Inflation

Notes: figures display the median peak responses of real GDP growth and HICP inflation to a one percent increase in central bank's total assets growth. 


\subsection{Why are effects of UMP shocks heterogeneous?}

We have shown that the effects of UMP shocks are substantially heterogeneous across countries. We now turn to investigate which structural features of the economy may be good predictors of this heterogeneity. To this end, we regress the estimated effects over a set of country-specific variables. First, we consider real GDP per capita as a proxy for the level of economic development of a country. The effects of UMP shocks may be different depending on the development of an economy through a variety of mechanisms. For instance, as countries develop, they shift resources from manufacturing to services, thus changing the sectoral composition of the economy. In the context of conventional monetary policy, the industry structure of a country may affect the transmission of monetary policy because sectors react differently to changes in the policy rate (e.g. Galesi and Rachedi, 2016; Georgiadis, 2015b).

We then include an index of soundness of the banking sector, which is proxied by the share of capital in total assets held by banks. The degree of soundness of countries' banking systems may have important implications for the effectiveness of ECB's non-standard policies, due to the specific nature of these measures. Indeed, expansionary policies should benefit banks' balance sheets, but these stimuli may not necessarily translate into additional lending if banks need to reestablish the solidity of their balance sheets. In this respect, a weak banking system may limit the effectiveness of UMP shocks, as it has already been shown in Boeckx et al. (2014).

Further, we consider the level of unemployment as a proxy for various factors such as aggregate demand conditions and labor market frictions. Expansionary UMP shocks may have a limited effect on consumption, employment, and economic activity, if households are borrowing constrained and thus, their demand is limited by current income. Similarly, frictions in the labor market like strict employment protection regulations, are expected to dampen the effectiveness of unconventional monetary policies by limiting job creation.

And finally we consider an index of ease of doing business developed by the World Bank. Values of this index lie in between between zero and one hundred, where a low level means that the regulatory environment is less conducive to the starting and operation of 
a firm. The index aggregates several indicators such as getting credit, enforcing contracts, or resolving insolvency, and we use it as a proxy for all those frictions and barriers which may impede the creation of new firms.

Figure 5: Peak responses of output growth and country characteristics
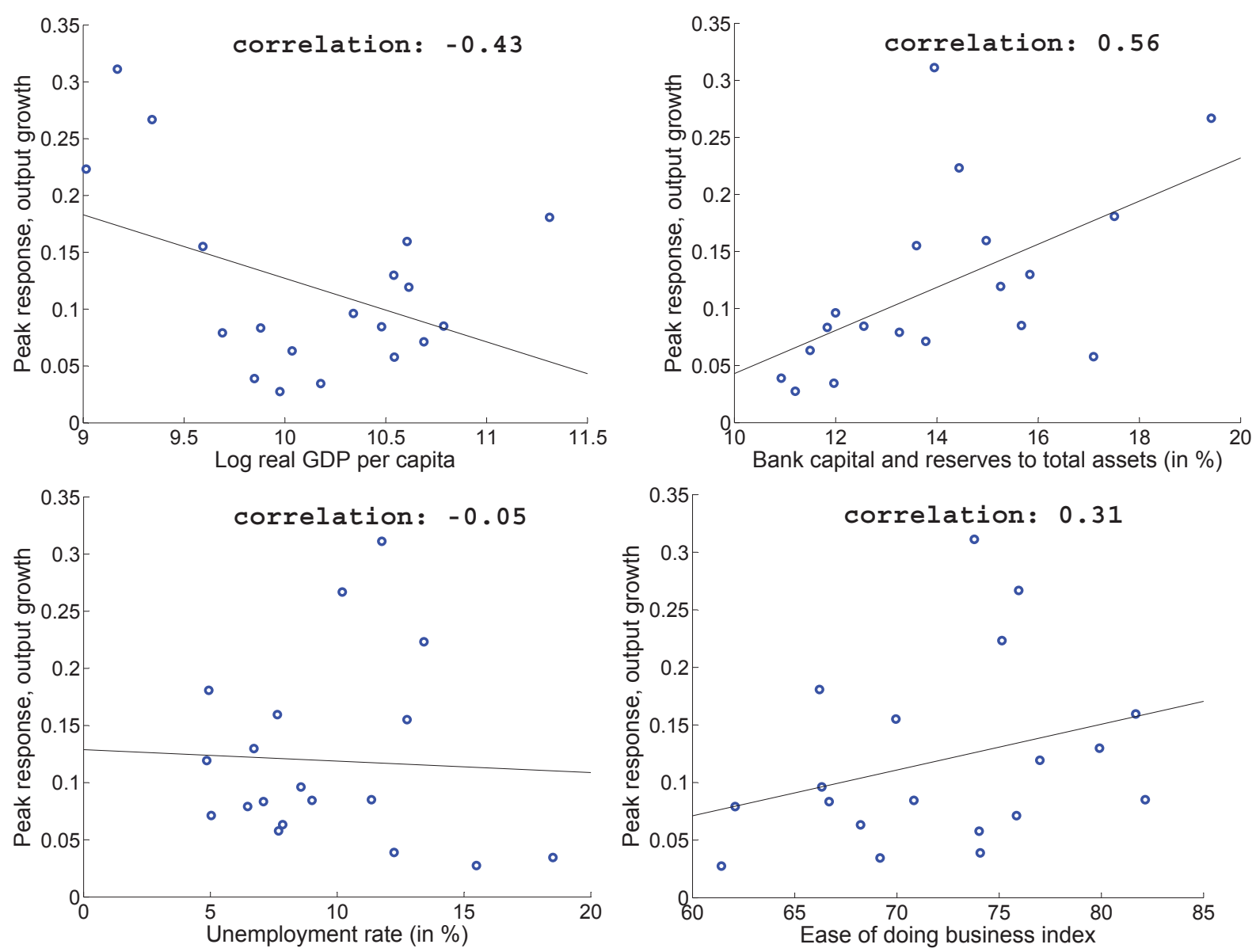

A preliminary inspection of the data shows that there is substantial correlation between the effects of UMP shocks and the selected country-specific characteristics. Figure 5 plots the peak responses of output growth against country-specific features under study. Less developed countries, as measured by real GDP per capita, benefit more from UMP shocks. At the same time, higher effects are observed in those countries with a more resilient banking sector. This result suggests the existence of a potential bottleneck in the effectiveness of UMP shocks which works via the bank lending channel. The unemployment rate does not correlate with effects, while there is some evidence that countries with 
more favorable regulatory systems for firms' operations are also those which experience the larger gains in output growth.

Figure 6: Peak responses of inflation and country characteristics
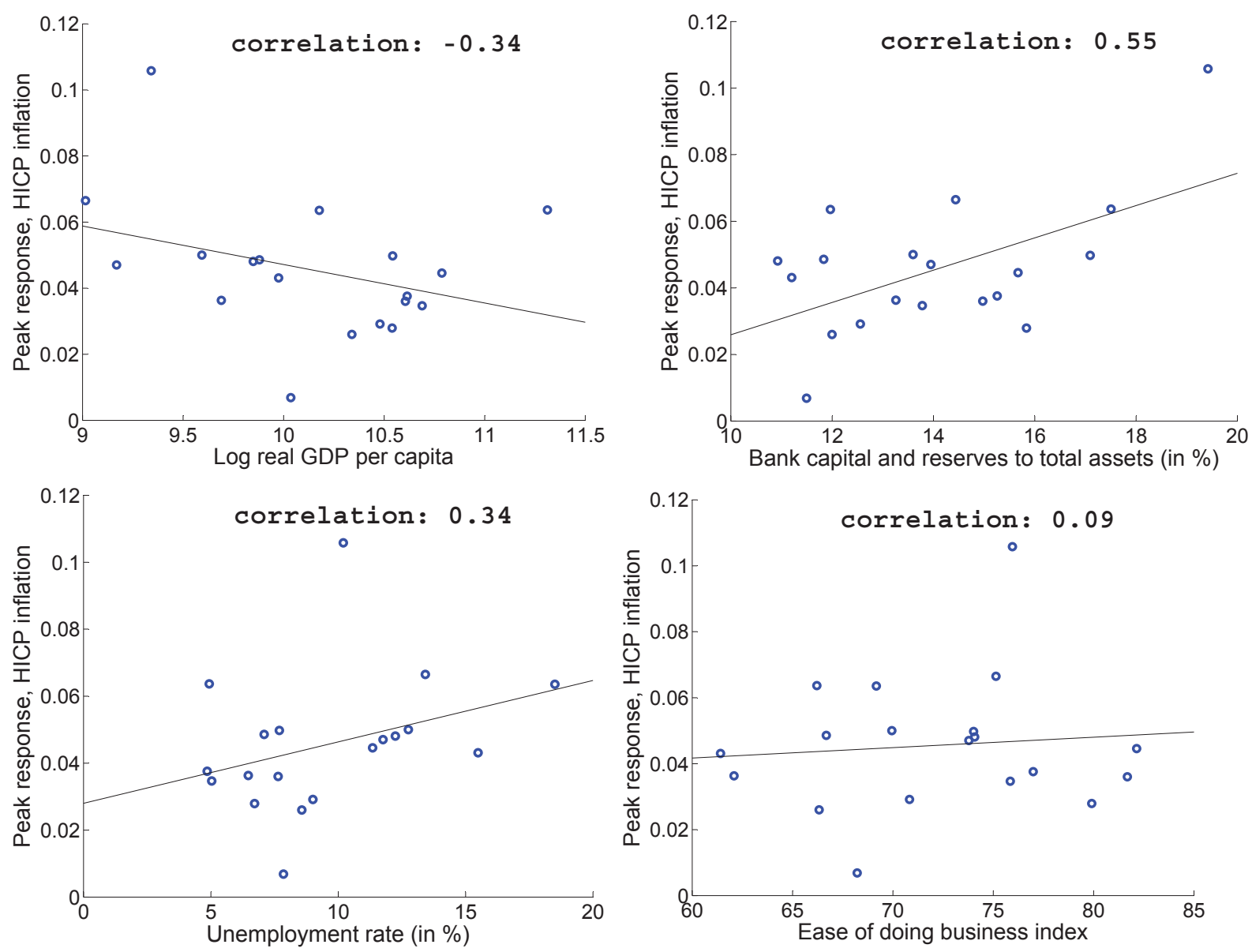

Regarding the effects on inflation, Figure 6 shows that again, countries which are either at a lower stage of development, or feature a sounder banking system, experience larger beneficial effects from UMP shocks. Higher unemployment rate associates with higher effects on inflation, while there is no clear relationship with regards to the ease of doing business index. 
Table 2: Effects of UMP shocks and country characteristics

\begin{tabular}{|c|c|c|c|c|c|c|}
\hline & \multicolumn{3}{|c|}{ Output growth } & \multicolumn{3}{|c|}{ Inflation } \\
\hline & $\begin{array}{l}\text { Direct } \\
\text { effect }\end{array}$ & $\begin{array}{l}\text { Spillover } \\
\text { effect }\end{array}$ & $\begin{array}{l}\text { Total } \\
\text { effect }\end{array}$ & $\begin{array}{l}\text { Direct } \\
\text { effect }\end{array}$ & $\begin{array}{c}\text { Spillover } \\
\text { effect }\end{array}$ & $\begin{array}{l}\text { Total } \\
\text { effect }\end{array}$ \\
\hline Real GDP per capita & $\begin{array}{l}-0.01 \\
(0.01)\end{array}$ & $\begin{array}{c}-0.07^{* * *} \\
(0.02)\end{array}$ & $\begin{array}{c}-0.08^{* *} \\
(0.03)\end{array}$ & $\begin{array}{c}0.00 \\
(0.01)\end{array}$ & $\begin{array}{l}-0.01 \\
(0.01)\end{array}$ & $\begin{array}{l}-0.01 \\
(0.00)\end{array}$ \\
\hline Banks' capital ratio & $\begin{array}{l}0.87^{*} \\
(0.41)\end{array}$ & $\begin{array}{l}1.10^{* *} \\
(0.43)\end{array}$ & $\begin{array}{l}1.98^{* *} \\
(0.76)\end{array}$ & $\begin{array}{c}0.31 \\
(0.26)\end{array}$ & $\begin{array}{c}0.48^{* * *} \\
(0.16)\end{array}$ & $\begin{array}{c}0.78^{* * *} \\
(0.19)\end{array}$ \\
\hline Unemployment rate & $\begin{array}{l}-0.09 \\
(0.11)\end{array}$ & $\begin{array}{l}-0.20 \\
(0.19)\end{array}$ & $\begin{array}{l}-0.29 \\
(0.21)\end{array}$ & $\begin{array}{c}0.11 \\
(0.14)\end{array}$ & $\begin{array}{l}0.17^{* *} \\
(0.07)\end{array}$ & $\begin{array}{c}0.27^{* * *} \\
(0.09)\end{array}$ \\
\hline Ease of doing business & $\begin{array}{c}0.05 \\
(0.15)\end{array}$ & $\begin{array}{c}0.09 \\
(0.19)\end{array}$ & $\begin{array}{c}0.14 \\
(0.28)\end{array}$ & $\begin{array}{l}-0.03 \\
(0.04)\end{array}$ & $\begin{array}{l}-0.05 \\
(0.04)\end{array}$ & $\begin{array}{l}-0.08 \\
(0.05)\end{array}$ \\
\hline Constant & $\begin{array}{c}0.00 \\
(0.14)\end{array}$ & $\begin{array}{l}0.61^{* *} \\
(0.25)\end{array}$ & $\begin{array}{l}0.61^{*} \\
(0.31)\end{array}$ & $\begin{array}{l}-0.03 \\
(0.09)\end{array}$ & $\begin{array}{c}0.08 \\
(0.05)\end{array}$ & $\begin{array}{c}0.05 \\
(0.06)\end{array}$ \\
\hline $\begin{array}{l}\text { Observations } \\
R^{2}\end{array}$ & $\begin{array}{c}19 \\
0.42\end{array}$ & $\begin{array}{c}19 \\
0.68\end{array}$ & $\begin{array}{c}19 \\
0.63\end{array}$ & $\begin{array}{c}19 \\
0.17\end{array}$ & $\begin{array}{c}19 \\
0.69\end{array}$ & $\begin{array}{c}19 \\
0.72\end{array}$ \\
\hline
\end{tabular}

Notes: Dependent variables are the median peak responses in output growth and inflation. Total effect refers to responses from the model with cross-country interactions, Direct effect refers to responses from the model without cross-country interactions, and Spillover effect is the difference between total and direct effects. Real GDP per capita is measured in logs. Regressors are measured as averages over 2007-2013. Robust Standard errors in parentheses. * **, *** respectively denote significance at the $10 \%, 5 \%$, and $1 \%$.

We conduct batteries of regressions where we regress the median peak responses of output growth and inflation on the full set of country-specific characteristics. ${ }^{3}$ We also distinguish between direct and spillover effects, since the latter may also depend on the various specific features of each economy. Table 2 reports results. Regarding output growth, regressions confirm the result that less developed countries, as measured by real GDP per capita, benefit more from UMP shocks. Interestingly, this relationship arises due to spillover effects, which suggests that less developed economies mostly gain from developments abroad. At the same time, UMP shocks benefit more those countries with

\footnotetext{
${ }^{3}$ Due to the limited amount of countries in the analysis, we limit the number of regressors and we focus on the effects on output and inflation for which we dispose of the full set of data points.
} 
a more resilient banking sector, and this relationship is strengthened by the presence of spillover effects. We observe a similar relationship for the effects on inflation, as UMP shocks benefit more those countries with a more resilient banking sector, but now just via spillover effects. Moreover, countries with higher levels of unemployment rate feature larger gains in inflation. Again, the effect is mostly driven by effects coming from abroad.

Interestingly, a model which abstracts from cross-country interactions would not be able to uncover any of the relationships that we have presented. Hence the international dimension of a country matters for determining the potential determinants of UMP shocks.

\subsection{Comparing unconventional and conventional measures}

The heterogeneity of effects across countries is substantial, and part of this dispersion can be explained by few determinants such as the level of economic development and the soundness of national banking systems. We investigate further on this issue by comparing the effects of UMP shocks against those arising from conventional monetary policy shocks.

First, we look at the effects of conventional monetary policy shocks for the aggregate of the euro area. Figure 7 plots the impulse responses to a 25 basis points reduction in the policy (MRO) rate. The policy rate falls and reverts to zero in less than one year. There is no significant response of the ECB's balance sheet, while output growth and inflation significantly increase. ${ }^{4}$ Interestingly, the EONIA-MRO spread significantly falls, while at the same time credit indicators (cost of credit, and new credit operations) do not react. Conventional monetary policy had been effective in relaxing the eurozone's bank lending conditions, but it lacked effectiveness on improving credit conditions, unlike unconventional measures. We read this evidence as suggesting that ECB's unconventional monetary policies, thanks to its more targeted nature, might have been more effective at reducing financial fragmentation and thus expanding credit. In the following of this section

\footnotetext{
${ }^{4}$ The estimated effects are large, and in line with estimates of recent literature, see for instance Baumeister and Benati (2013) for the US and UK. Such high elasticities possibly arise because of the small variation of the policy rate in the data, particularly over the last part of the sample in which the rate attains its zero lower bound. As it will be shown in the following of the section, for the purpose of comparing the effectiveness of UMP and CMP shocks, we focus on country-specific deviations from the average euro area effects once we rescale the sizes of the two shocks so that both policies lead to a $1 \%$ peak effect on output growth of the euro area.
} 
we will provide further evidence on this point by exploiting the cross-country variation of the estimated effects.

Figure 7: Euro area wide responses to an conventional monetary policy shock
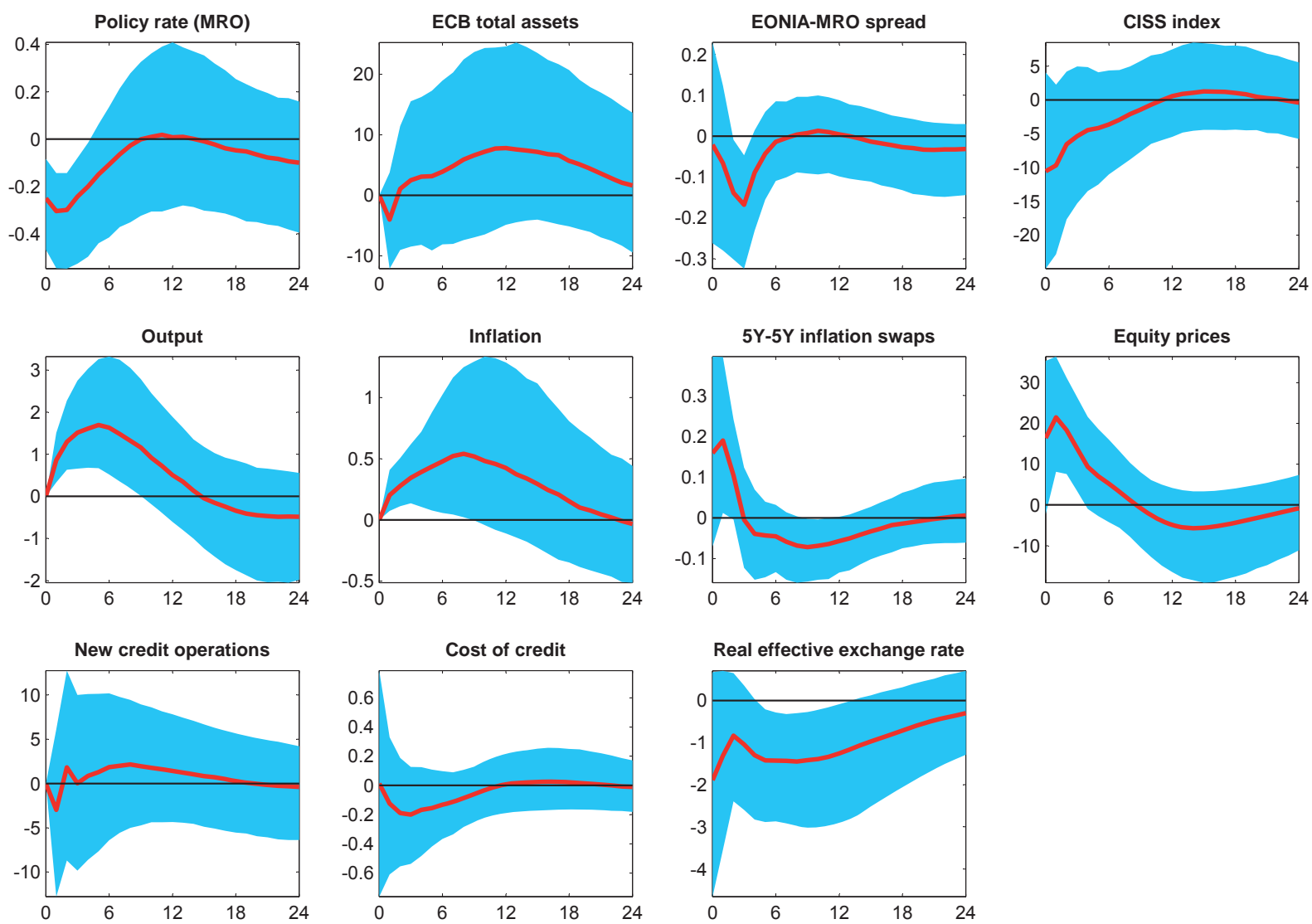

Notes: responses to a 25 basis points reduction in policy rate. Solid red lines represent the median estimates and blue areas denote the 16 th and 84 th percentiles.

Further, inflation expectations increase and reach a peak of $0.2 \%$ after one month, even though the response is barely statistically significant. Real equity prices significantly increase and the exchange rate significantly depreciates. All in all, this evidence suggests that the conventional instrument of monetary policy has been effective in averting a worsening of the crisis in the eurozone, at least until the short-term rate reached its zero lower bound. These results go in line with other works which have shown the effectiveness of the conventional monetary policy in the aftermath of the recent recession (e.g. Ciccarelli et al., 2013). 
Now we turn to the effects across countries of conventional monetary policy (CMP) shocks, and compare them with those arising from UMP shocks. Given the linearity of the model, we first rescale the sizes of UMP and CMP shocks so that both disturbances lead to a $1 \%$ peak effect on output growth of the euro area. We subsequently compute the country-specific effects of the two shocks, by calculating the peak responses for each variable under study. Figure 8 plots results: the $x$-scale measures the effects of a CMP shock (a reduction in the official interest rate), while the $y$-scale measures the effects of UMP shock (expansion of central bank's balance sheet), and we also plot a solid black 45 degrees line. Given our normalization, the effects on output growth of the CMP and UMP shocks are on average of similar size, but with important cross-country variation.

Figure 8: Effects of unconventional and conventional monetary policy shocks

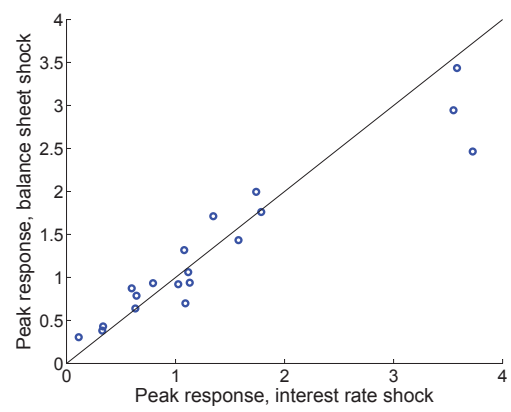

(a) Output growth

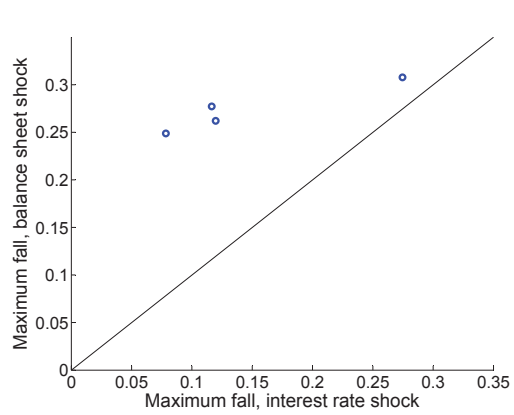

(d) Cost of credit

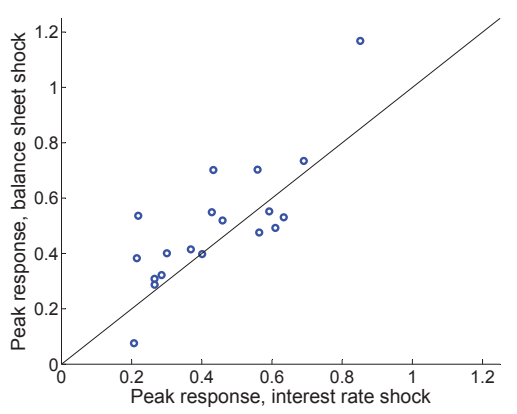

(b) Inflation

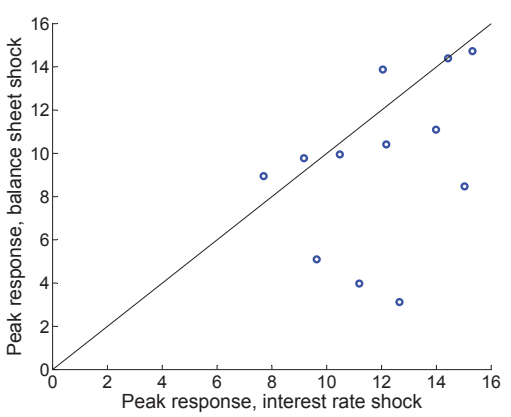

(e) Equity prices

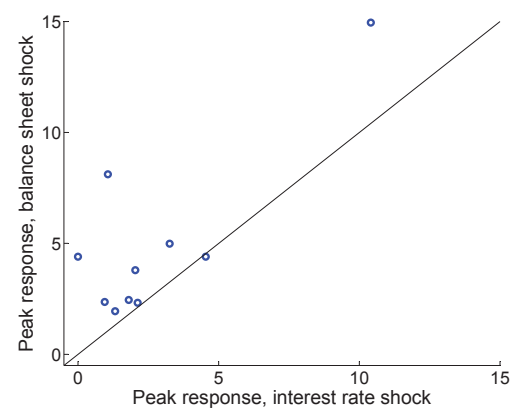

(c) New credit operations

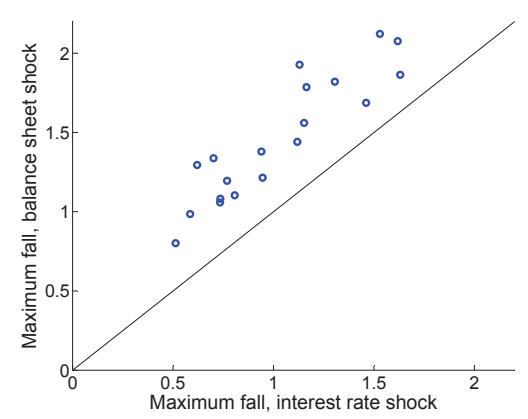

(f) Real effective exchange rate

Notes: the $x$-scale measures the country-specific effects of a reduction in the official interest rate (conventional monetary policy shock), while the $y$-scale measures the effects of an expansion of central bank's balance sheet (unconventional monetary policy shock). Both shocks are rescaled to lead to a $1 \%$ peak effect on output growth of the euro area. For cost of credit and real effective exchange rate we report the maximum fall (which equals the through response with reversed sign), and the peak response for the rest of variables. 45 degrees line in solid black.

Compared to conventional reductions in the interest rate, UMP shocks lead to a larger increase in growth of new credit operations and to a larger fall in the cost of credit. These 
results suggests that ECB's unconventional monetary policies, thanks to its targeted nature, have been particularly effective at reducing financial fragmentation and thus expanding credit. As additional results, it is worth noticing that UMP shocks also lead to a greater depreciation of the exchange rate and higher inflation. Conversely, reductions in the official interest rate lead to larger increases in equity prices.

\section{Robustness}

In this section we conduct several robustness checks. First, we investigate how results change when considering an economy with a binding zero lower bound on the nominal short-term interest rate. Second, we explore the composition of the ECB's balance sheet and consider an alternative measure of central bank's assets. Third, we assess the role of the signaling channel when considering alternative measures of inflation expectations. Finally, we investigate how results change when considering the shadow interest rate as alternative policy instrument.

\subsection{Dealing with the zero lower bound}

In order to identify the exogenous balance sheet shocks we have postulated a zero impact effect on the MRO rate, so to impose orthogonality between unconventional and conventional monetary policy shocks. We experiment an alternative identification strategy in which we assume that the MRO rate cannot react even at longer horizons, to capture the effects of UMP shocks when the economy is at the zero lower bound. Specifically, we follow Baumeister and Benati (2013) and implement this additional restriction by setting to zero all the coefficients in the structural VAR's interest rate rule. In practice, the restriction holds up to 24 months after the shock, which is in line with the horizon of 8 quarters employed in Baumeister and Benati (2013). Second column of Figure 9 plots the results. The effects are virtually identical to those of the benchmark model. Since in the benchmark model the response of the MRO rate is not statistically different from zero at any horizon, results do not drastically change when imposing the zero lower bound. 
Figure 9: Effects of UMP shocks: alternative specifications
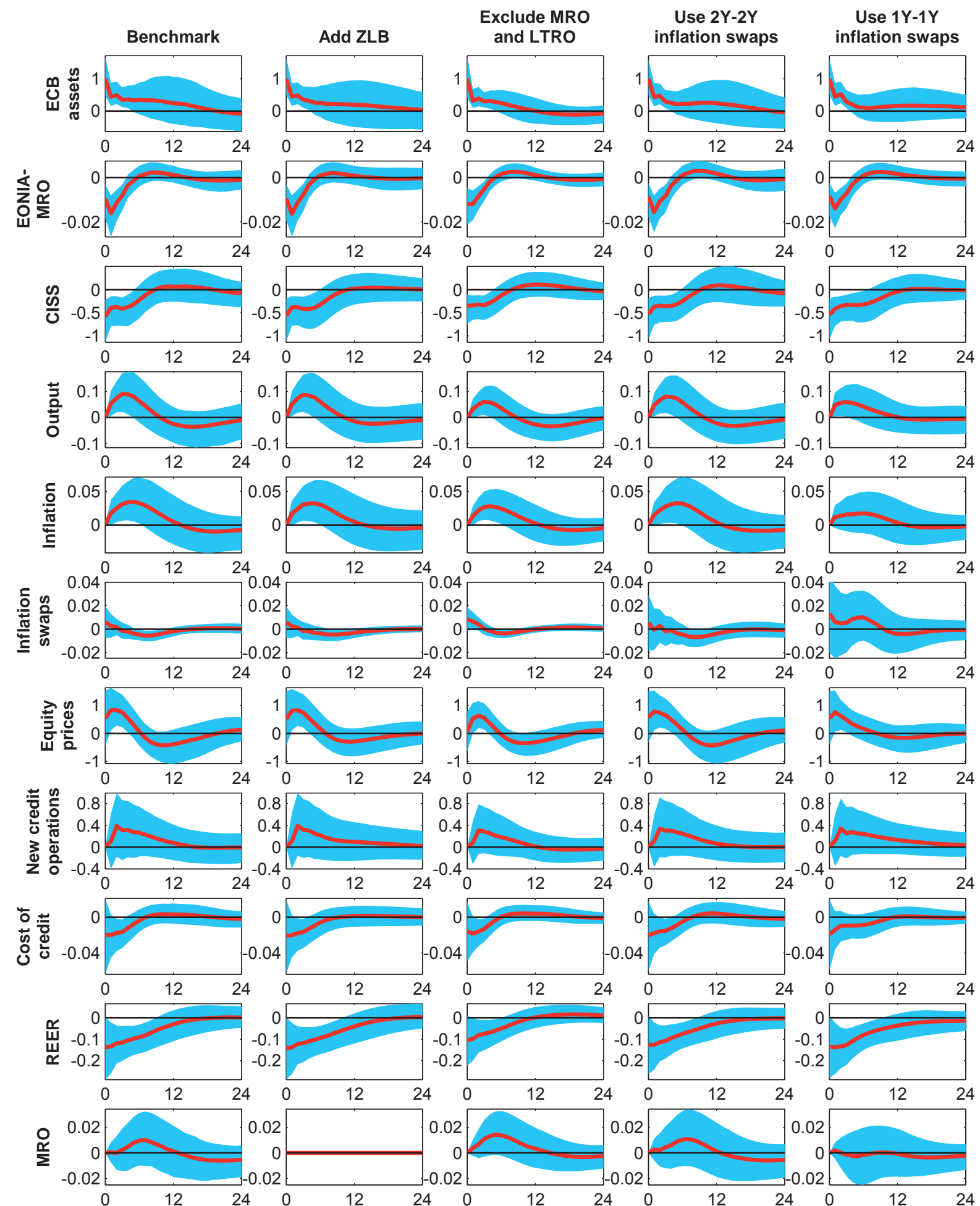

Notes: solid red lines represent the median estimates and blue areas denote the 16th and 84th percentiles. 


\subsection{Excluding MRO and LTRO components of ECB assets}

MRO and LTRO shares in total assets of the ECB dramatically rose over the years 2012 and 2013, and such increase may play an important role as an endogenous response to financial stress. In our alternative identification scheme we consider ECB total assets which exclude these components, and keep the same restrictions as in the benchmark identification scheme. Third column of Figure 9 plots the estimated impulse responses to an exogenous expansion of the balance sheet using this alternative identification scheme. Results are qualitatively, and in most of the cases, also quantitatively similar to those of the benchmark model. This finding suggests that our benchmark identification scheme successfully controls for endogenous reactions which arise from MRO and LTRO components of the ECB's balance sheet.

\subsection{Alternative measures of inflation expectations}

Our benchmark results suggest that exogenous expansions of the central bank's balance sheet have a positive effect on inflation expectations, but the effect is not statistically significant. To further shed light on this result we also analyze an alternative measure of inflation expectations, in particular the 2-years-on-2-years and 1-year-on-1-year inflation swaps. Our guess is that these measures, by capturing expectations at shorter horizons, are more reactive to exogenous movements of the balance sheet. Fourth and fifth columns of Figure 9 plot the estimated impulse responses to an exogenous expansion of the balance sheet, when using respectively the 2-years-on-2-years and 1-year-on-1-year inflation swaps. As we would have expected, the impulse responses are more volatile, being these alternative inflation measures more reactive to shocks. However, results are qualitatively unchanged, and in particular, UMP shocks do not significantly increase inflation expectations.

\subsection{Shadow interest rate as alternative policy instrument}

We discussed that the ECB's balance sheet may not be a perfect indicator of each of the unconventional monetary measures undertaken by the ECB, but that it is probably a good 
proxy to a policy instrument. We verify our claim by comparing the impulse responses to an orthogonal shock to the shadow interest rate, which is a recently popularized indicator of the monetary policy stance when nominal interest rates reach the zero lower bound, see for instance Krippner (2013) and Wu and Xia (2016).

We employ data on the shadow interest rate for the euro area developed in $\mathrm{Wu}$ and Xia (2016). This rate is estimated using data on one-month forward rates at different maturities which range from 3 months to 10 years. Compared to the central bank's balance sheet, the shadow interest rate can capture not only the effects of asset purchases, but also of forward guidance, intended as the central bank's communications about its future policy intentions.

We identify the UMP shock by imposing the same sign restrictions employed in the benchmark identification scheme. That is, a fall in the shadow interest rate should not increase the CISS index and should reduce the EONIA-MRO spread on impact and after the subsequent three months. To distinguish from a conventional monetary policy shock, we impose a zero impact restriction on the MRO policy rate, and to account for inertia in effects we also impose a zero impact restriction on output growth, inflation, and credit growth.

Figure 10 plots the impulse responses to a 25 basis points reduction in the shadow interest rate. The shadow interest rate falls and reverts to zero in less than one year. The response of the MRO rate, required to be zero on impact, is not significant at any horizon, confirming the orthogonality with unconventional monetary policy reactions. Euro area real GDP growth and inflation significantly increase and display a hump-shaped behavior. Similarly to the benchmark identification scheme, inflation expectations do not significantly react to the shock. Overall, impulse responses have the same sign as those arising from an exogenous expansion of the central bank's balance sheet. This result confirms that focussing at changes in the ECB's balance sheet may be a good indicator for the monetary policy stance in the eurozone. 
Figure 10: Effects of 25 basis points reduction in shadow interest rate
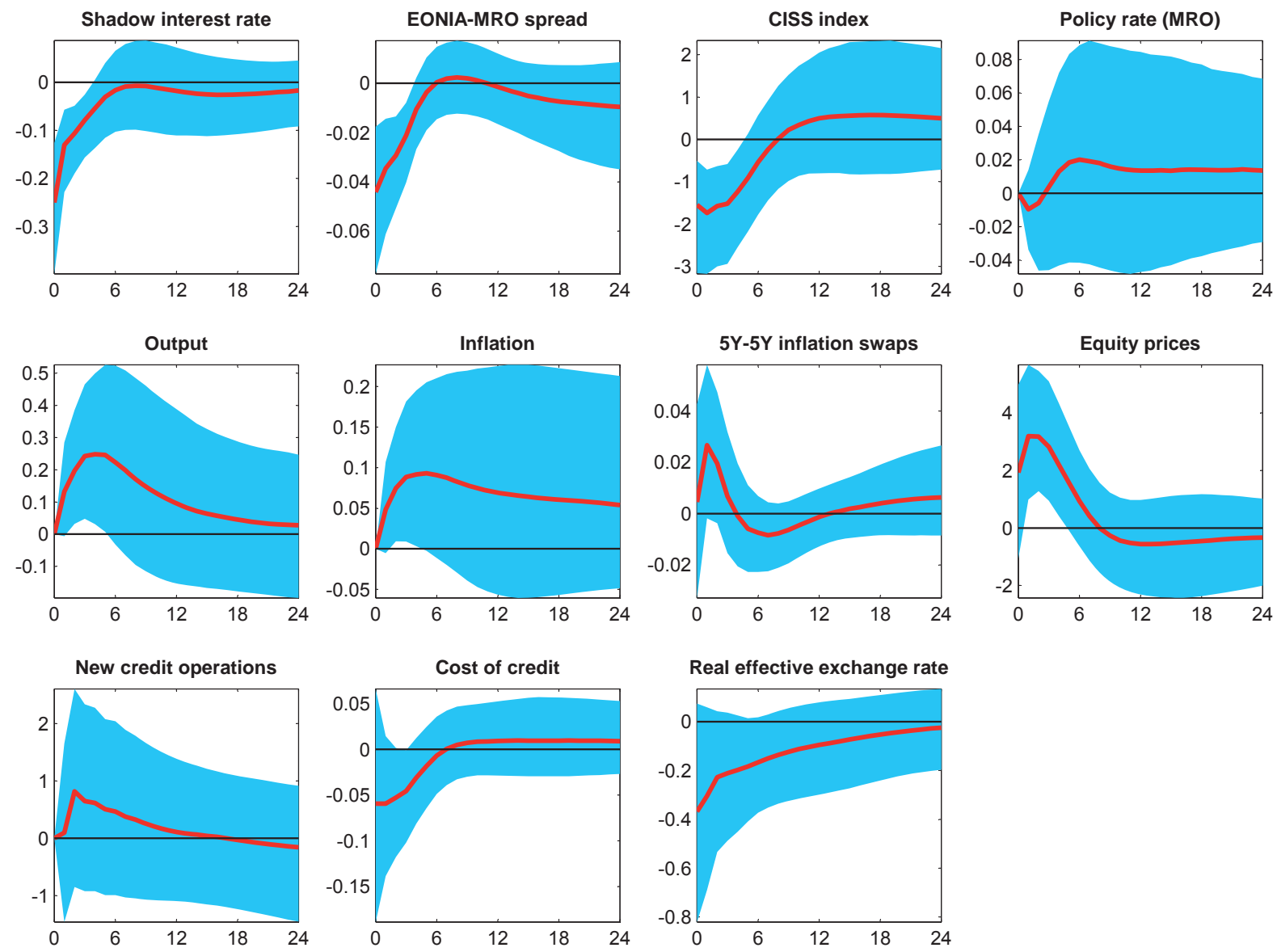

Notes: solid red lines represent the median estimates and blue areas denote the 16th and 84th percentiles. 


\section{Conclusions}

In this paper we assess the macroeconomic and financial effects of the recent ECB's unconventional monetary policies by estimating a global VAR which includes all the current members of the monetary union. The multi-country structure of the GVAR explicitly takes into account national macro-financial dynamics as well as cross-country interdependencies. This feature allows us to better capture the relevant transmission channels of monetary policy, as well as to properly assess the size and dispersion of the effects of UMP shocks across euro area countries.

We estimate our model over the period January 2007 - September 2015, and study the effects of UMP shocks both for the whole euro area and for all member countries. Unconventional monetary policies have beneficial effects on aggregate output and inflation, confirming their role as a stabilization tool. UMP shocks also increase credit, equity prices, and lead to a depreciation of the exchange rate. At the disaggregated level, most euro area members benefit from UMP shocks, but with a substantial degree of heterogeneity. Spillover effects account for a sizable fraction of such dispersion, and substantially amplify the effects of UMP shocks. Countries with less fragile banking systems benefit the most from unconventional monetary policies, both in terms of direct and spillover effects. When comparing the effects of UMP shocks with those arising from standard reductions in the official rate, we find that unconventional measures are particularly effective in reducing firms' financing costs and boosting credit. We read this evidence as suggesting that the ECB's unconventional monetary policies, thanks to its more targeted nature, have been particularly effective at reducing financial fragmentation and thus expanding credit. 


\section{References}

Abbassi, P. and T. Linzert (2012) "The effectiveness of monetary policy in steering money market rates during the financial crisis". Journal of Macroeconomics, 34(4), 945-954.

Arias, J., D. Caldara, and J. F. Rubio-Ramirez (2015) "The systematic component of monetary policy in SVARs: an agnostic identification procedure". FRB International Finance Discussion Paper, 1131.

Arias, J., J. F. Rubio-Ramirez, and D. F. Waggoner (2014) "Inference Based on SVARs Identified with Sign and Zero Restrictions: Theory and Applications". FRB Atlanta Working Paper, 2014-1.

Baumeister, C., and L. Benati (2013) "Unconventional Monetary Policy and the Great Recession: Estimating the Macroeconomic Effects of a Spread Compression at the Zero Lower Bound". International Journal of Central Banking, 9(2), 165-212.

Beirne, J., L. Dalitz, J. Ejsing, M. Grothe, S. Manganelli, F. Monar, B. Sahel, M. Susec, J. Tapking, and T. Vong (2011) "The impact of the Eurosystem's covered bond purchase programme on the primary and secondary markets". ECB Occasional Paper, 122.

Bluwstein, K., and F. Canova (2016) "Beggar-Thy-Neighbor? The International Effects of ECB Unconventional Monetary Policy Measures". International Journal of Central Banking, 12(3), 69-120.

Boeckx, J., M. Dossche, and G. Peersman (2014) "Effectiveness and transmission of the ECB's balance sheet policies". Working Paper Research, 275, National Bank of Belgium.

Ciccarelli, M., A. Maddaloni, and J.-L. Peydró (2013) "Heterogeneous transmission mechanism: monetary policy and financial fragility in the eurozone". Economic Policy, 28(75), 459-512. 
Dees, S., F. di Mauro, M. H. Pesaran, and L. V. Smith (2007) "Exploring the international linkages of the euro area: a global VAR analysis". Journal of Applied Econometrics, 22(1), 1-38.

Draghi, M. (2013) "Stable Euro, Strong Europe". Speech at the Wirtschaftstag, Berlin, 25 June.

Draghi, M. (2014) "Monetary Policy Communication in Turbulent Times". Speech at the Conference De Nederlandsche Bank, Amsterdam, 24 April.

Feldkircher, M., and F. Huber (2016a) "The International Transmission of US Shocks - Evidence from Bayesian Global Vector Autoregressions". European Economic Review, 81, 167-188.

Feldkircher, M., and F. Huber (2016b) "Unconventional US Monetary Policy: New Tools, Same Channels?". OeNB Working Paper Series, 221.

Galesi, A., and O. Rachedi (2016) "Structural Transformation, Services Deepening, and the Transmission of Monetary Policy". Banco de España Working Paper, 1615.

Gambacorta, L., B. Hofmann, and G. Peersman (2014) "The effectiveness of unconventional monetary policy at the zero lower bound: A cross-country analysis". Journal of Money, Credit and Banking, 46(4), 615-642.

Georgiadis, G. (2015a) "Determinants of global spillovers from US monetary policy". Journal of International Money and Finance, 67, 41-61.

Georgiadis, G. (2015b) "Examining asymmetries in the transmission of monetary policy in the euro area: Evidence from a mixed cross-section global VAR model". European Economic Review, 75, 195-215.

Georgiadis, G. (2015c) "To Bi, or not to Bi? Differences in Spillover Estimates from Bilateral and Multilateral Multi-country Models". Federal Reserve Bank of Dallas Globalization and Monetary Policy Institute Working Paper, 256. 
Giannone, D., M. Lenza, H. Pill, and L. Reichlin (2011) "Non-standard Monetary Policy Measures and Monetary Developments". ECB Working Paper Series, 1290, European Central Bank.

Gilchrist, S., and B. Mojon (2014) "Credit Risk in the Euro Area". NBER Working Papers, 20041.

Gimeno, R., and E. Ortega (2015) "The Evolution of Inflation Expectations in Euro Area Markets". mimeo.

Harvey, A. C. (1990) "Forecasting, Structural Time Series Models and the Kalman Filter". Cambridge University Press.

Holló, D., M. Kremer, and M. Lo Duca (2012) "CISS - A Composite Indicator of Systemic Stress in the Financial System". ECB Working Paper Series, 1426, European Central Bank.

Kapetanios, G., H. Mumtaz, I. Stevens, and K. Theodoridis (2012) "Assessing the economy-wide effects of quantitative easing". The Economic Journal, 122(564), F316-F347.

Kremer, M. (2016) "Macroeconomic effects of financial stress and the role of monetary policy: a VAR analysis for the euro area". International Economics and Economic Policy, 13(1), 105-138.

Krippner, L. (2013) "Measuring the stance of monetary policy in zero lower bound environments". Economic Letters, 118(1), 135-138.

Krishnamurthy, A., and A. Vissing-Jorgensen (2013) "The ins and outs of LSAPs". Federal Reserve Bank of Kansas CityŠs Jackson Hole Symposium on the Global Dimensions of Unconventional Monetary Policy, Jackson Hole, Wyoming.

Lenza, M., H. Pill, and L. Reichlin (2010) "Monetary policy in exceptional times". Economic Policy, 25(62), 295-339. 
Peersman, G., and F. Smets (2003) "The monetary transmission mechanism in the euro area: evidence from VAR analysis". Monetary policy transmission in the Euro area, 36-55.

Pesaran, M. H., T. Schuermann, and S. M. Weiner (2004) "Modeling regional interdependencies using a global error-correcting macroeconometric model". Journal of Business \& Economic Statistics, 22(2), 129-162.

Schenkelberg, Heike, and Sebastian Watzka (2013) "Real effects of quantitative easing at the zero lower bound: Structural VAR-based evidence from Japan". Journal of International Money and Finance, 33, 327-357.

Timmer, M., A. A. Erumban, R. Gouma, B. Los, U. Temurshoev, G. J. de Vries, I. A. Arto, V. A. A. Genty, F. Neuwahl, J. Francois, and O. Pindyuk (2012) "The world input-output database (WIOD): contents, sources and methods". No. 20120401. Institute for International and Development Economics.

van den End, J. W. and C. Pattipeilohy (2015) "Central bank balance sheet policies and inflation expectations". Working Paper Series, 473, Netherlands Central Bank, Research Department.

Wu, J. C., and F. D. Xia (2004) "Measuring the macroeconomic impact of monetary policy at the zero lower bound". Journal of Money, Credit and Banking, 48(2-3), 253-291. 


\section{A Tables and Figures}

Table A.1: Description of variables in the GVAR and data sources

\begin{tabular}{|c|c|}
\hline Variable & Description and data sources \\
\hline \multicolumn{2}{|l|}{$\underline{\text { Common variables }}$} \\
\hline ECB total assets & $\begin{array}{l}\text { Year-on-year rate of growth of ECB total assets. Data on balance sheet of ECB, including } \\
\text { components of assets MRO and LTRO, come from the Statistical Data Warehouse of the } \\
\text { ECB. }\end{array}$ \\
\hline MRO rate & $\begin{array}{l}\text { Interest rate on marginal refinancing operations (MRO). Data come from the Statistical Data } \\
\text { Warehouse of the ECB. }\end{array}$ \\
\hline EONIA-MRO spread & $\begin{array}{l}\text { Spread between the Euro OverNight Index Average (EONIA) and the MRO rate. Data on } \\
\text { EONIA come from the Statistical Data Warehouse of the ECB. }\end{array}$ \\
\hline CISS index & $\begin{array}{l}\text { Index of Composite Index of Systemic Stress as developed in Holló et al., the index ranges } \\
\text { from } 0 \text { (no stress) to } 1 \text { (total stress). Data come from the Statistical Data Warehouse of the } \\
\text { ECB. }\end{array}$ \\
\hline Inflation swaps & $\begin{array}{l}\text { Measures of inflation expectations computed using the 5-years-on-5-years, 2-years-on-2-years, } \\
\text { and 1-year-on-1-year inflation swaps. Data come from Gimeno and Ortega (2015). }\end{array}$ \\
\hline Shadow interest rate & $\begin{array}{l}\text { It measures the stance of monetary policy when the zero lower bound binds. Unlike the } \\
\text { observed short-term interest rate, the shadow rate is not bounded below by zero percent. } \\
\text { Data come from Wu and Xia (2016), and available at the following link: http://faculty. } \\
\text { chicagobooth.edu/jing.wu/research/data/WX.html. }\end{array}$ \\
\hline \multicolumn{2}{|l|}{ Country-specific variables } \\
\hline Real GDP growth & $\begin{array}{l}\text { Year-on-year rate of growth of real GDP. Real GDP are at quarterly frequency, and we con- } \\
\text { struct monthly measures using a Chow-Lin interpolation procedure where monthly industrial } \\
\text { production and the volume of sales in wholesale and retail trade are the reference series. Data } \\
\text { on real GDP, industrial production, and volume of sales in wholesale and retail trade come } \\
\text { from Eurostat. }\end{array}$ \\
\hline HICP inflation & $\begin{array}{l}\text { Year-on-year rate of growth of Harmonized Index of Consumer Price (HICP). HICP data } \\
\text { come from Eurostat, and we apply a seasonal adjustment to the data using the Census X12 } \\
\text { procedure. }\end{array}$ \\
\hline New credit operations & $\begin{array}{l}\text { Year-on-year rate of growth of new credit operations to non-financial corporations. Data on } \\
\text { new credit operations are seasonally adjusted using the Census X12 procedure, and they are } \\
\text { deflated using the HICP. Data come from the European Central Bank. }\end{array}$ \\
\hline Cost of credit & $\begin{array}{l}\text { Spread between the yields on non-financial corporations bonds relative to the yield on do- } \\
\text { mestic government securities of matched maturities. Data come from Gilchrist and Mojon } \\
\text { (2014). }\end{array}$ \\
\hline Equity prices & $\begin{array}{l}\text { Year-on-year rate of growth of real equity prices. We use a monthly index of share prices, } \\
\text { calculated by quotations of the stock exchange. The index is deflated using the HICP. Data } \\
\text { come from the Monthly Monetary and Financial Statistics Dataset of OECD. }\end{array}$ \\
\hline Effective exchange rate & Monthly real (CPI-based) effective exchange rate. Data come from BIS. \\
\hline \multicolumn{2}{|l|}{ Weights } \\
\hline Trade weights & $\begin{array}{l}\text { Weights employed to construct foreign-specific variables } Y^{*} \text {. They are constructed as aver- } \\
\text { ages of shares of exports and imports over the period 2008-2011. Data come from the World } \\
\text { Input-Output Database. }\end{array}$ \\
\hline GDP weights & $\begin{array}{l}\text { Weights employed to construct euro area variables } \tilde{Y} \text { and for aggregating country-specific } \\
\text { impulse responses at the euro area level. They are constructed as shares of real GDP in the } \\
\text { euro area, averaged over the period 2008-2015. }\end{array}$ \\
\hline
\end{tabular}


Table A.2: Country-specific models' specification

\begin{tabular}{|c|c|c|c|c|c|c|}
\hline Country & Output & Inflation & Equity prices & New credit operations & Cost of credit & Real effective FX \\
\hline Austria & $\mathrm{X}$ & $\mathrm{X}$ & $\mathrm{X}$ & $\mathrm{X}$ & & $\mathrm{X}$ \\
\hline Belgium & $\mathrm{X}$ & $\mathrm{X}$ & $\mathrm{X}$ & $\mathrm{X}$ & & $\mathrm{X}$ \\
\hline Cyprus & $\mathrm{X}$ & $\mathrm{X}$ & & & & $\mathrm{X}$ \\
\hline Estonia & $\mathrm{X}$ & $\mathrm{X}$ & & & & $\mathrm{X}$ \\
\hline Finland & $\mathrm{X}$ & $\mathrm{X}$ & $\mathrm{X}$ & $\mathrm{X}$ & & $\mathrm{X}$ \\
\hline France & $\mathrm{X}$ & $\mathrm{X}$ & $\mathrm{X}$ & $\mathrm{X}$ & $\mathrm{X}$ & $\mathrm{X}$ \\
\hline Germany & $\mathrm{X}$ & $\mathrm{X}$ & $\mathrm{X}$ & $\mathrm{X}$ & $\mathrm{X}$ & $\mathrm{X}$ \\
\hline Greece & $\mathrm{X}$ & $\mathrm{X}$ & $\mathrm{X}$ & & & $\mathrm{X}$ \\
\hline Ireland & $\mathrm{X}$ & $\mathrm{X}$ & $\mathrm{x}$ & $\mathrm{x}$ & & $\mathrm{X}$ \\
\hline Italy & $\mathrm{X}$ & $\mathrm{X}$ & $\mathrm{X}$ & $\mathrm{X}$ & $\mathrm{X}$ & $\mathrm{X}$ \\
\hline Latvia & $\mathrm{X}$ & $\mathrm{X}$ & & & & $\mathrm{X}$ \\
\hline Lithuania & $\mathrm{X}$ & $\mathrm{X}$ & & & & $\mathrm{X}$ \\
\hline Luxembourg & $\mathrm{X}$ & $\mathrm{X}$ & $\mathrm{X}$ & & & $\mathrm{X}$ \\
\hline Malta & $\mathrm{X}$ & $\mathrm{X}$ & & & & $\mathrm{X}$ \\
\hline Netherlands & $\mathrm{X}$ & $\mathrm{X}$ & $\mathrm{X}$ & $\mathrm{x}$ & & $\mathrm{X}$ \\
\hline Portugal & $\mathrm{X}$ & $\mathrm{X}$ & $\mathrm{X}$ & $\mathrm{X}$ & & $\mathrm{X}$ \\
\hline Slovak Republic & $\mathrm{X}$ & $\mathrm{X}$ & & & & $\mathrm{X}$ \\
\hline Slovenia & $\mathrm{X}$ & $\mathrm{X}$ & & & & $\mathrm{X}$ \\
\hline Spain & $\mathrm{X}$ & $\mathrm{X}$ & $\mathrm{X}$ & $\mathrm{X}$ & $\mathrm{X}$ & $\mathrm{X}$ \\
\hline
\end{tabular}

Table A.3: Description of variables for structural characteristics and data sources

\begin{tabular}{|c|c|}
\hline Variable & Description and data sources \\
\hline Real GDP per capita & $\begin{array}{l}\text { GDP per capita is gross domestic product divided by midyear population. Data are in } \\
\text { constant } 2005 \text { U.S. dollars. Average over the period 2007-2013. Data come from Global } \\
\text { Financial Development Database, The World Bank. }\end{array}$ \\
\hline Banks' capital ratio & $\begin{array}{l}\text { Ratio of bank capital and reserves to total assets. Capital includes tier } 1 \text { capital (paid-up } \\
\text { shares and common stock), and total regulatory capital. Total assets include all nonfinancial } \\
\text { and financial assets. Average over the period 2007-2013. Data come from Global Financial } \\
\text { Development Database, The World Bank. }\end{array}$ \\
\hline Unemployment rate & $\begin{array}{l}\text { Total unemployed over active population, where unemployment follows the ILO definition. } \\
\text { Average over the period 2007-2013. Data come from Eurostat. }\end{array}$ \\
\hline Ease of doing business & $\begin{array}{l}\text { Index based on the distance to frontier score, which captures the gap between an economy's } \\
\text { performance and a measure of best practice across the entire sample of } 36 \text { indicators for } \\
10 \text { Doing Business topics: Starting a Business, Dealing with Construction Permits, Get- } \\
\text { ting Electricity Registering Property, Getting Credit, Protecting Minority Investors, Paying } \\
\text { Taxes, Trading Across Borders, Enforcing Contracts, Resolving Insolvency. The distance } \\
\text { to frontier score aids in assessing the absolute level of regulatory performance and how it } \\
\text { improves over time. An economy's distance to frontier is reflected on a scale from } 0 \text { to 100, } \\
\text { where } 0 \text { represents the lowest performance and } 100 \text { represents the frontier. Average over the } \\
\text { period 2010-2013. Data come from The World Bank. }\end{array}$ \\
\hline
\end{tabular}


Figure A.1: Peak responses of output and inflation to UMP shocks

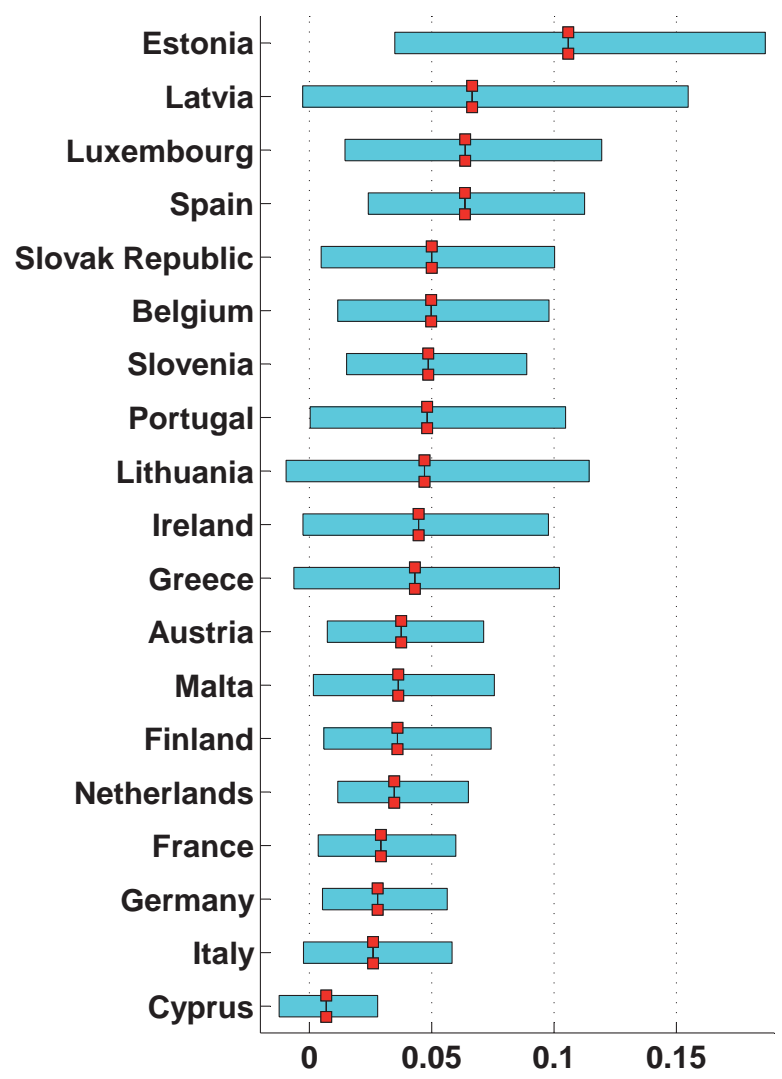

(a) Inflation

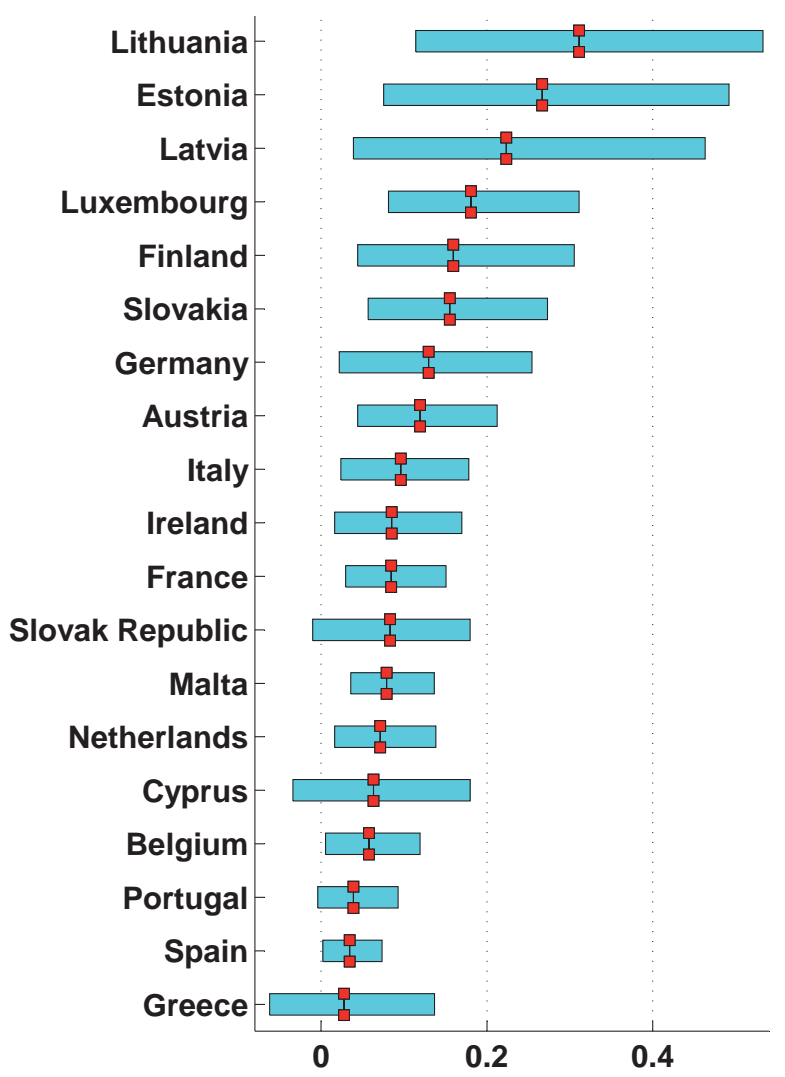

(b) Output growth

Notes: red dots represent median peak responses of HICP inflation and real GDP growth, light blue bars denote the 16th and 84 th percentiles. 
Figure A.2: Sample autocorrelation of GVAR residuals
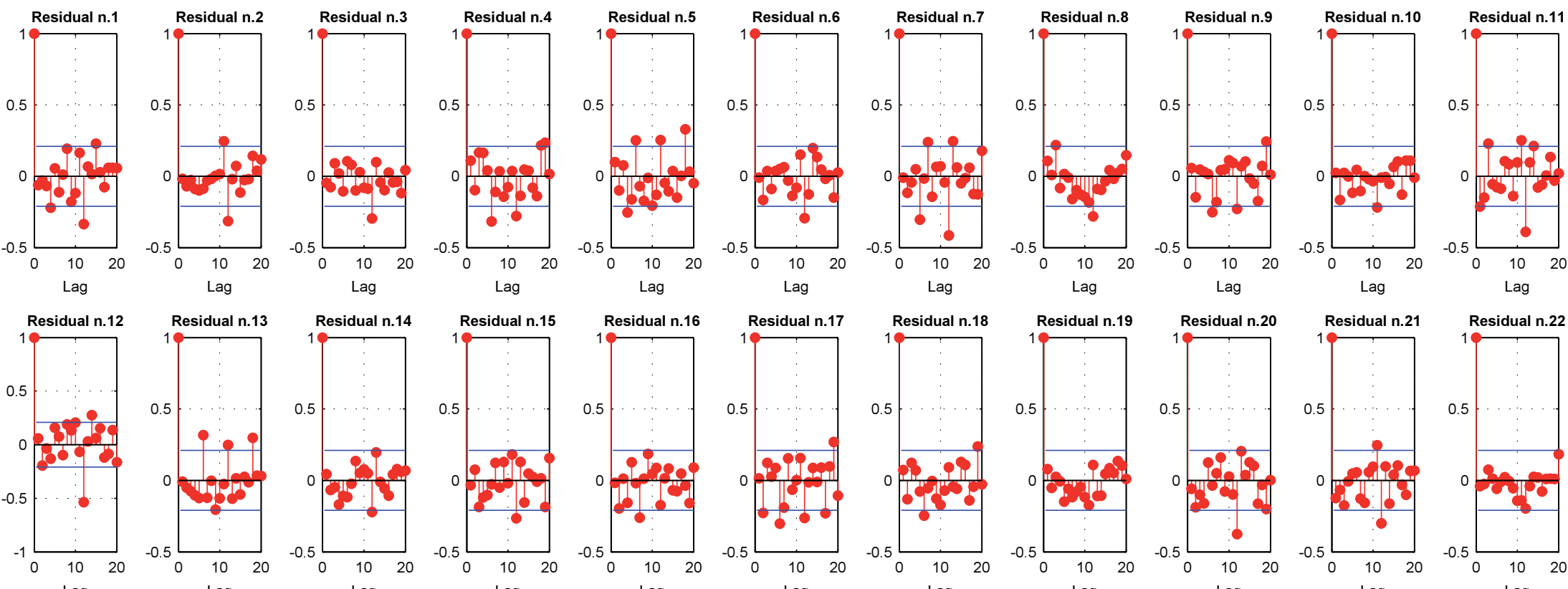

Residual $n .17$
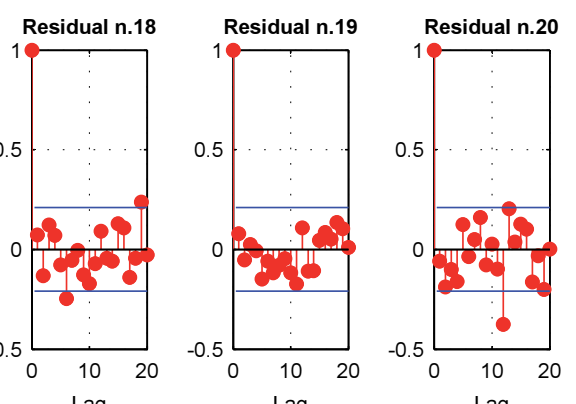

Residual n.21

Residual $n .22$
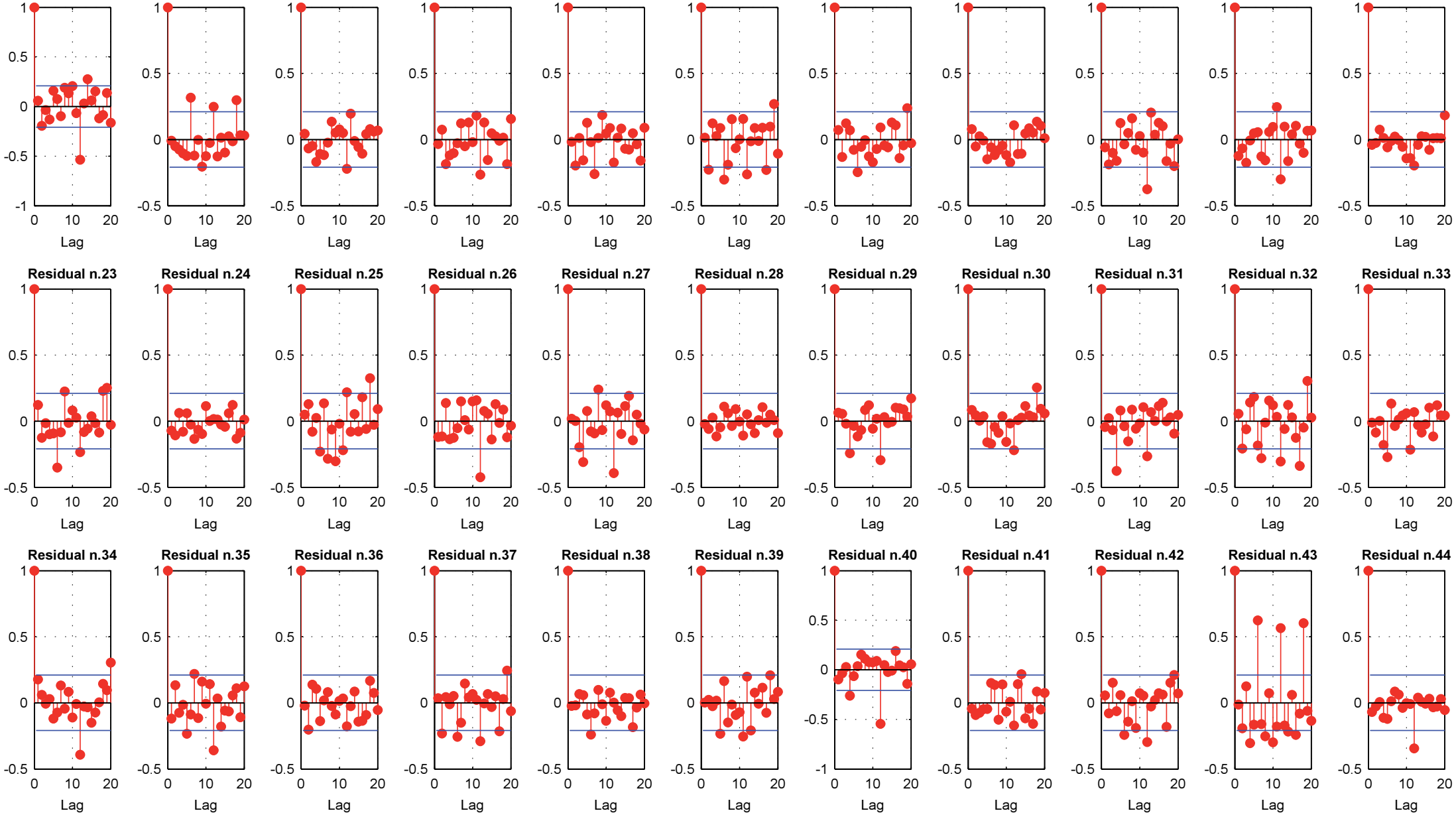
Figure A.3: (Continued) Sample autocorrelation of GVAR residuals
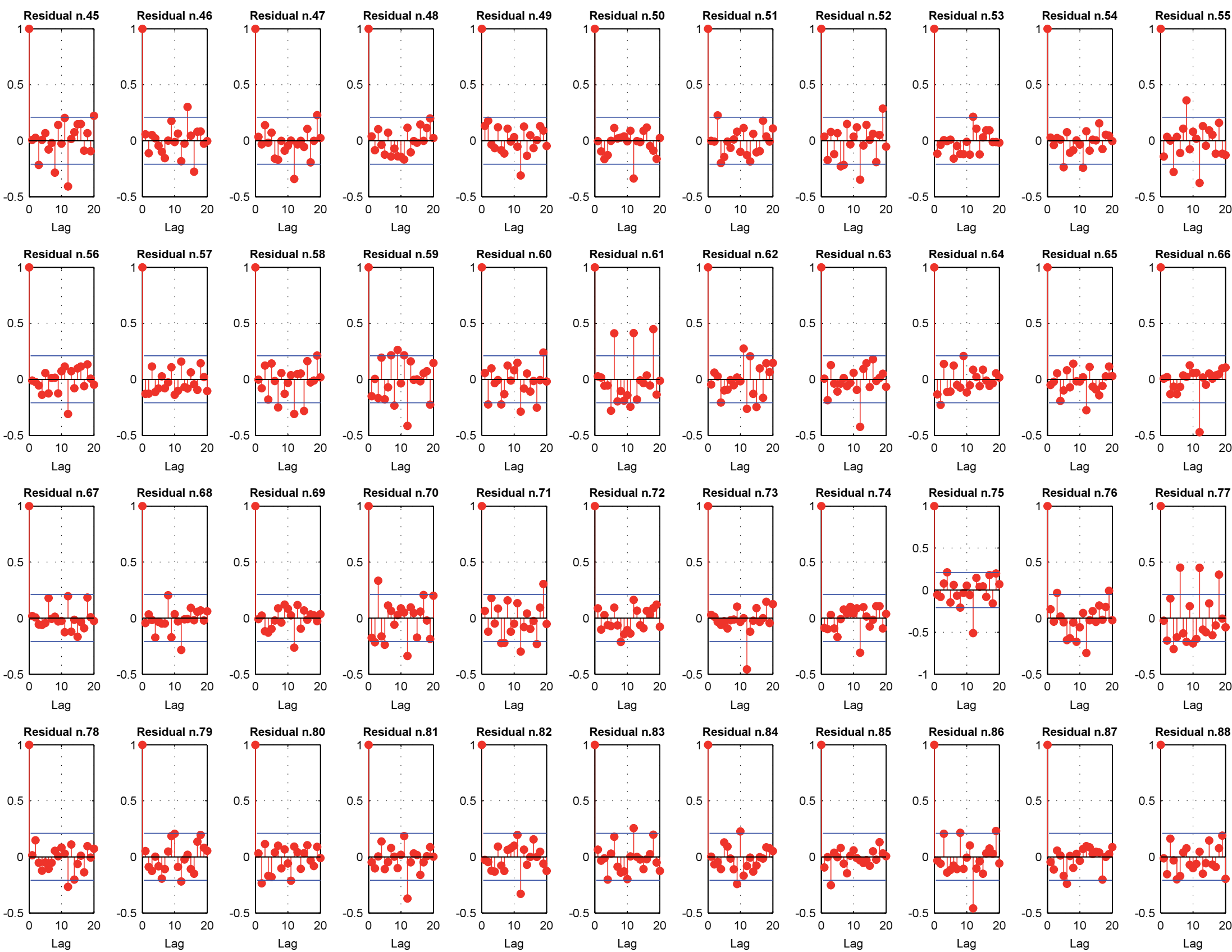
Figure A.4: Effects of one percent increase in balance sheet on output: all countries
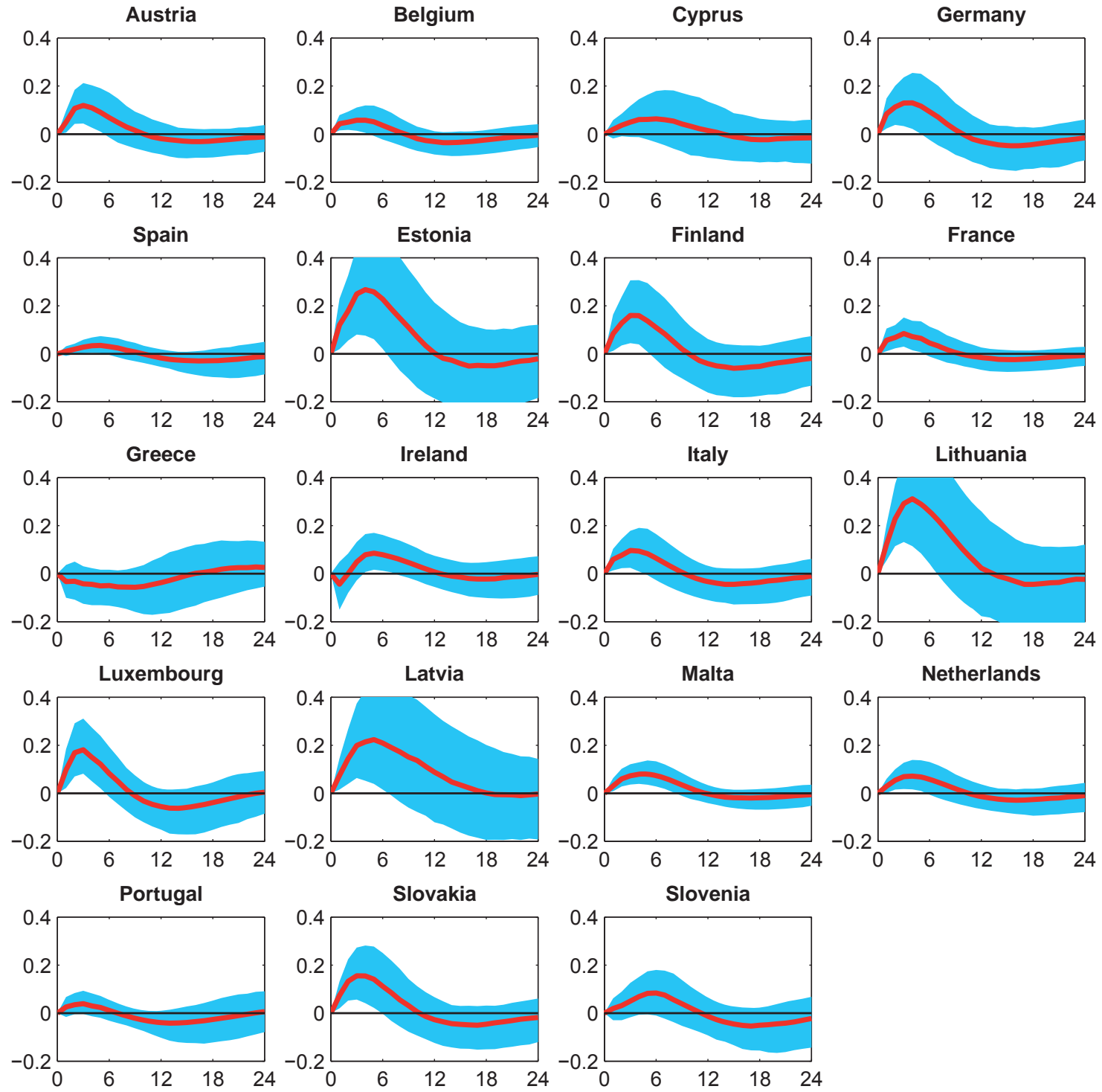

Notes: solid red lines represent the median estimates and blue areas denote the 16th and 84th percentiles. 
Figure A.5: Effects of one percent increase in balance sheet on inflation: all countries
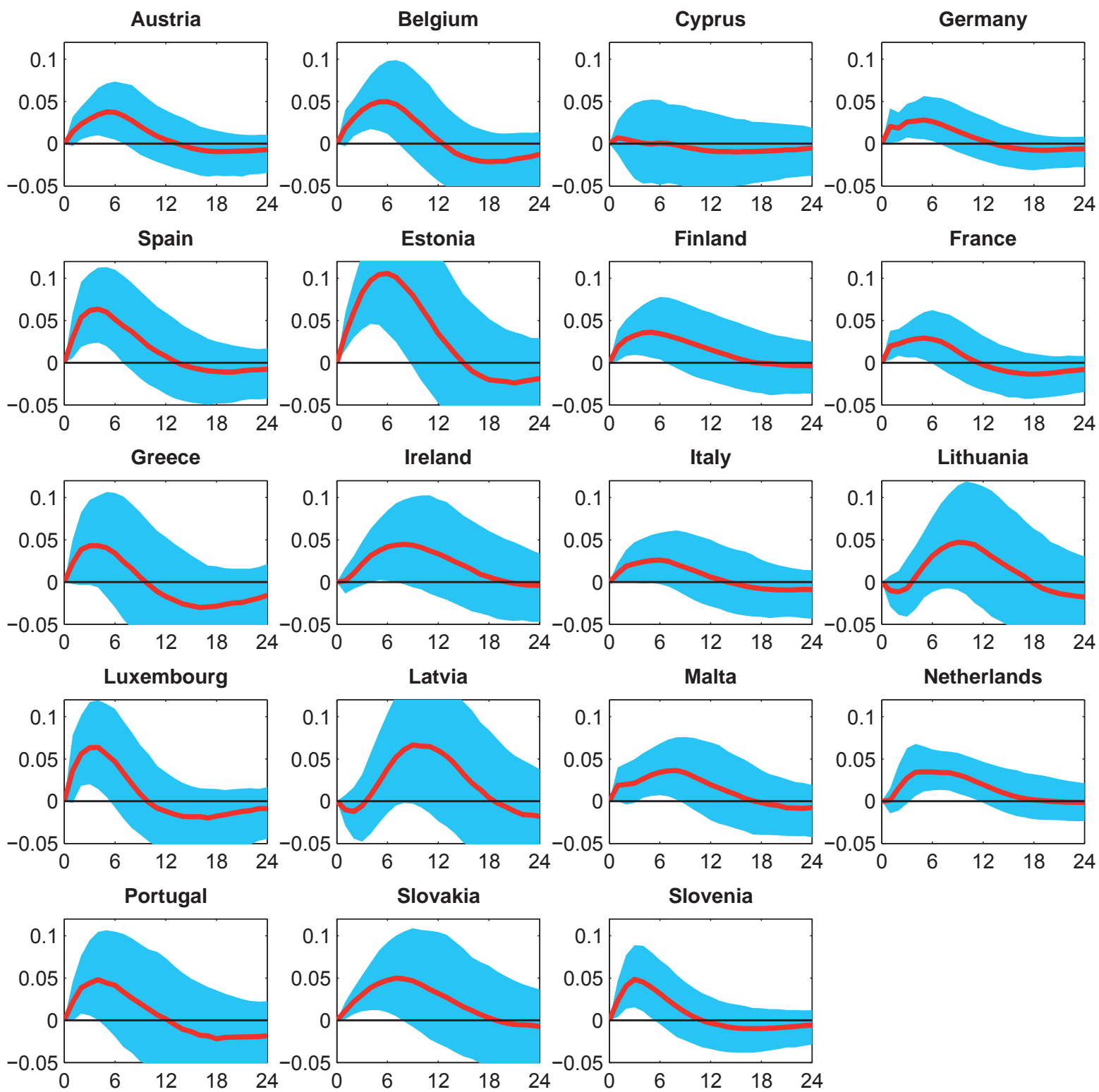

Notes: solid red lines represent the median estimates and blue areas denote the 16 th and 84 th percentiles. 
Figure A.6: Effects of one percent increase in balance sheet on real equity prices: all countries
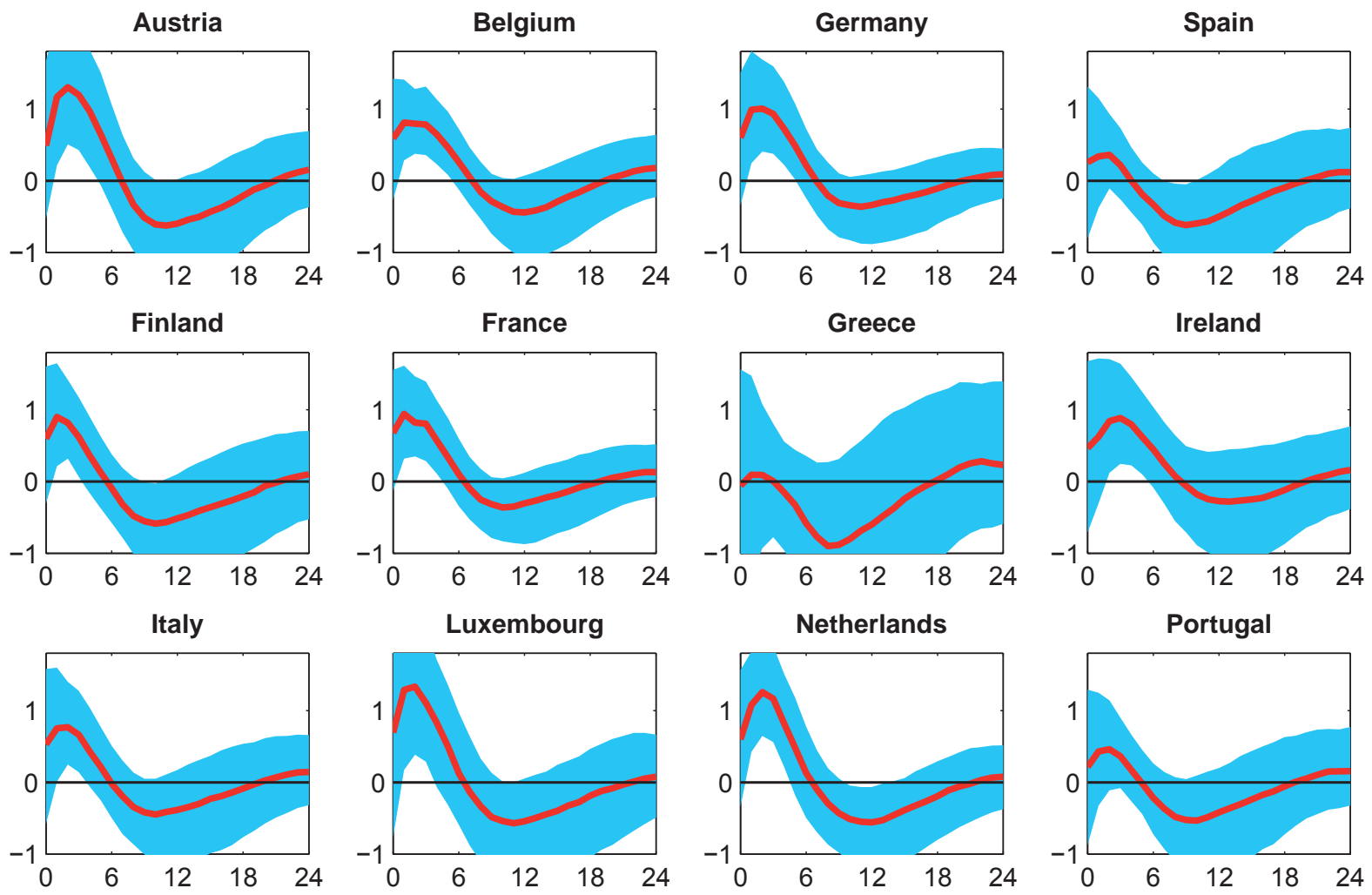

Notes: solid red lines represent the median estimates and blue areas denote the 16th and 84th percentiles. 
Figure A.7: Effects of one percent increase in balance sheet on volume of new credit operations: all countries
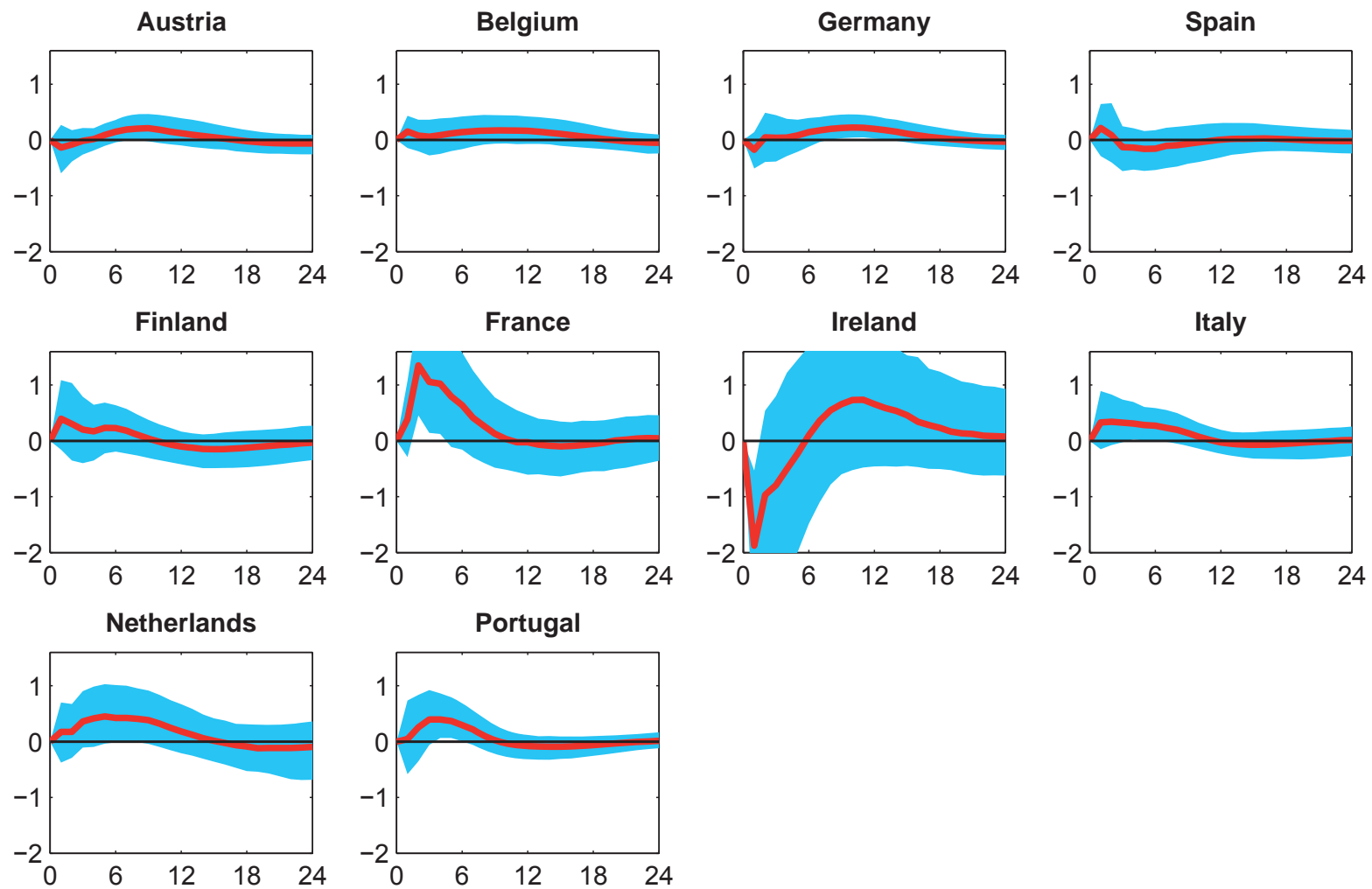

Notes: solid red lines represent the median estimates and blue areas denote the 16 th and 84 th percentiles. 
Figure A.8: Effects of one percent increase in balance sheet on real effective exchange rate: all countries
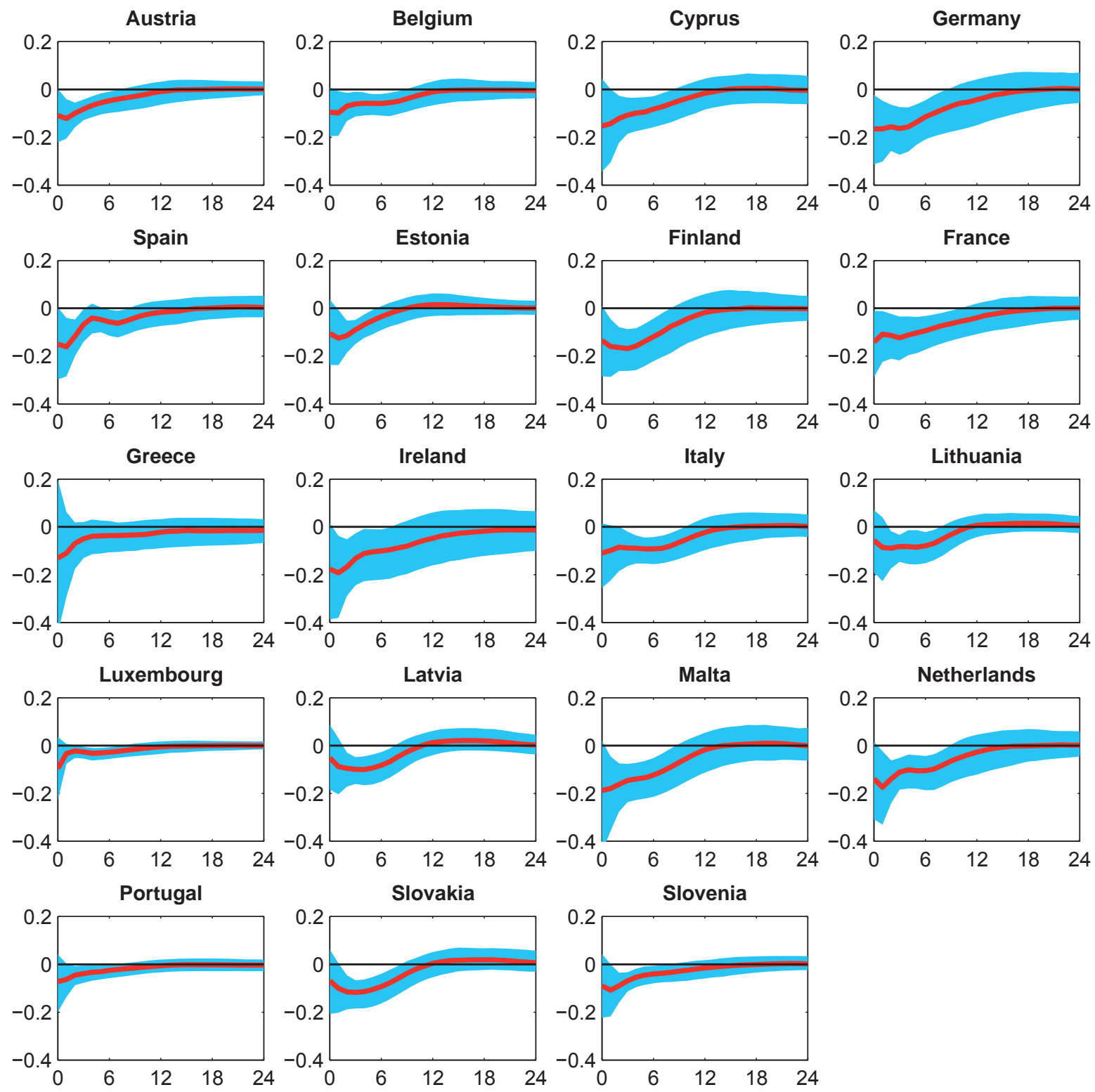

Notes: solid red lines represent the median estimates and blue areas denote the 16th and 84th percentiles. 


\title{
BANCO DE ESPAÑA PUBLICATIONS
}

\author{
WORKING PAPERS
}

1511 PATRICIA GÓMEZ-GONZÁLEZ: Financial innovation in sovereign borrowing and public provision of liquidity.

1512 MIGUEL GARCÍA-POSADA and MARCOS MARCHETTI: The bank lending channel of unconventional monetary policy: the impact of the VLTROs on credit supply in Spain.

1513 JUAN DE LUCIO, RAÚL MÍNGUEZ, ASIER MINONDO and FRANCISCO REQUENA: Networks and the dynamics of firms' export portfolio.

1514 ALFREDO IBÁÑEZ: Default near-the-default-point: the value of and the distance to default.

1515 IVÁN KATARYNIUK and JAVIER VALLÉS: Fiscal consolidation after the Great Recession: the role of composition.

1516 PABLO HERNÁNDEZ DE COS and ENRIQUE MORAL-BENITO: On the predictability of narrative fiscal adjustments.

1517 GALO NUÑO and CARLOS THOMAS: Monetary policy and sovereign debt vulnerability.

1518 CRISTIANA BELU MANESCU and GALO NUÑO: Quantitative effects of the shale oil revolution.

1519 YAEL V. HOCHBERG, CARLOS J. SERRANO and ROSEMARIE H. ZIEDONIS: Patent collateral, investor commitment and the market for venture lending.

1520 TRINO-MANUEL ÑIGUEZ, IVAN PAYA, DAVID PEEL and JAVIER PEROTE: Higher-order risk preferences, constant relative risk aversion and the optimal portfolio allocation.

1521 LILIANA ROJAS-SUÁREZ and JOSÉ MARÍA SERENA: Changes in funding patterns by Latin American banking systems: how large? how risky?

1522 JUAN F. JIMENO: Long-lasting consequences of the European crisis.

1523 MAXIMO CAMACHO, DANILO LEIVA-LEON and GABRIEL PEREZ-QUIROS: Country shocks, monetary policy expectations and ECB decisions. A dynamic non-linear approach.

1524 JOSÉ MARÍA SERENA GARRALDA and GARIMA VASISHTHA: What drives bank-intermediated trade finance? Evidence from cross-country analysis.

1525 GABRIELE FIORENTINI, ALESSANDRO GALESI and ENRIQUE SENTANA: Fast ML estimation of dynamic bifactor models: an application to European inflation.

1526 YUNUS AKSOY and HENRIQUE S. BASSO: Securitization and asset prices.

1527 MARÍA DOLORES GADEA, ANA GÓMEZ-LOSCOS and GABRIEL PEREZ-QUIROS: The Great Moderation in historical perspective. Is it that great?

1528 YUNUS AKSOY, HENRIQUE S. BASSO, RON P. SMITH and TOBIAS GRASL: Demographic structure and macroeconomic trends.

1529 JOSÉ MARÍA CASADO, CRISTINA FERNÁNDEZ and JUAN F. JIMENO: Worker flows in the European Union during the Great Recession.

1530 CRISTINA FERNÁNDEZ and PILAR GARCÍA PEREA: The impact of the euro on euro area GDP per capita.

1531 IRMA ALONSO ÁLVAREZ: Institutional drivers of capital flows.

1532 PAUL EHLING, MICHAEL GALLMEYER, CHRISTIAN HEYERDAHL-LARSEN and PHILIPP ILLEDITSCH: Disagreement about inflation and the yield curve.

1533 GALO NUÑO and BENJAMIN MOLL: Controlling a distribution of heterogeneous agents.

1534 TITO BOERI and JUAN F. JIMENO: The unbearable divergence of unemployment in Europe.

1535 OLYMPIA BOVER: Measuring expectations from household surveys: new results on subjective probabilities of future house prices.

1536 CRISTINA FERNÁNDEZ, AITOR LACUESTA, JOSÉ MANUEL MONTERO and ALBERTO URTASUN: Heterogeneity of markups at the firm level and changes during the great recession: the case of Spain.

1537 MIGUEL SARMIENTO and JORGE E. GALÁN: The influence of risk-taking on bank efficiency: evidence from Colombia.

1538 ISABEL ARGIMÓN, MICHEL DIETSCH and ÁNGEL ESTRADA: Prudential filters, portfolio composition and capital ratios in European banks.

1539 MARIA M. CAMPOS, DOMENICO DEPALO, EVANGELIA PAPAPETROU, JAVIER J. PÉREZ and ROBERTO RAMOS: Understanding the public sector pay gap.

1540 ÓSCAR ARCE, SAMUEL HURTADO and CARLOS THOMAS: Policy spillovers and synergies in a monetary union.

1601 CHRISTIAN CASTRO, ÁNGEL ESTRADA and JORGE MARTÍNEZ: The countercyclical capital buffer in Spain: an analysis of key guiding indicators. 
1602 TRINO-MANUEL ÑÍGUEZ and JAVIER PEROTE: Multivariate moments expansion density: application of the dynamic equicorrelation model.

1603 ALBERTO FUERTES and JOSÉ MARÍA SERENA: How firms borrow in international bond markets: securities regulation and market segmentation.

1604 ENRIQUE ALBEROLA, IVÁN KATARYNIUK, ÁNGEL MELGUIZO and RENÉ OROZCO: Fiscal policy and the cycle in Latin America: the role of financing conditions and fiscal rules.

1605 ANA LAMO, ENRIQUE MORAL-BENITO and JAVIER J. PÉREZ: Does slack influence public and private labour market interactions?

1606 FRUCTUOSO BORRALLO, IGNACIO HERNANDO and JAVIER VALLÉS: The effects of US unconventional monetary policies in Latin America.

1607 VINCENZO MERELLA and DANIEL SANTABÁRBARA: Do the rich (really) consume higher-quality goods? Evidence from international trade data.

1608 CARMEN BROTO and MATÍAS LAMAS: Measuring market liquidity in US fixed income markets: a new synthetic indicator.

1609 MANUEL GARCÍA-SANTANA, ENRIQUE MORAL-BENITO, JOSEP PIJOAN-MAS and ROBERTO RAMOS: Growing like Spain: 1995-2007.

1610 MIGUEL GARCÍA-POSADA and RAQUEL VEGAS: Las reformas de la Ley Concursal durante la Gran Recesión.

1611 LUNA AZAHARA ROMO GONZÁLEZ: The drivers of European banks' US dollar debt issuance: opportunistic funding in times of crisis?

1612 CELESTINO GIRÓN, MARTA MORANO, ENRIQUE M. QUILIS, DANIEL SANTABÁRBARA and CARLOS TORREGROSA: Modelling interest payments for macroeconomic assessment.

1613 ENRIQUE MORAL-BENITO: Growing by learning: firm-level evidence on the size-productivity nexus.

1614 JAIME MARTÍNEZ-MARTÍN: Breaking down world trade elasticities: a panel ECM approach.

1615 ALESSANDRO GALESI and OMAR RACHEDI: Structural transformation, services deepening, and the transmission of monetary policy.

1616 BING XU, ADRIAN VAN RIXTEL and HONGLIN WANG: Do banks extract informational rents through collateral?

1617 MIHÁLY TAMÁS BORSI: Credit contractions and unemployment.

1618 MIHÁLY TAMÁS BORSI: Fiscal multipliers across the credit cycle.

1619 GABRIELE FIORENTINI, ALESSANDRO GALESI and ENRIQUE SENTANA: A spectral EM algorithm for dynamic factor models.

1620 FRANCISCO MARTÍ and JAVIER J. PÉREZ: Spanish public finances through the financial crisis.

1621 ADRIAN VAN RIXTEL, LUNA ROMO GONZÁLEZ and JING YANG: The determinants of long-term debt issuance by European banks: evidence of two crises.

1622 JAVIER ANDRÉS, ÓSCAR ARCE and CARLOS THOMAS: When fiscal consolidation meets private deleveraging.

1623 CARLOS SANZ: The effect of electoral systems on voter turnout: evidence from a natural experiment.

1624 GALO NUÑO and CARLOS THOMAS: Optimal monetary policy with heterogeneous agents.

1625 MARÍA DOLORES GADEA, ANA GÓMEZ-LOSCOS and ANTONIO MONTAÑÉS: Oil price and economic growth: a long story?

1626 PAUL DE GRAUWE and EDDIE GERBA: Stock market cycles and supply side dynamics: two worlds, one vision?

1627 RICARDO GIMENO and EVA ORTEGA: The evolution of inflation expectations in euro area markets.

1628 SUSANA PÁRRAGA RODRÍGUEZ: The dynamic effect of public expenditure shocks in the United States.

1629 SUSANA PÁRRAGA RODRÍGUEZ: The aggregate effects of government incometransfer shocks - EU evidence.

1630 JUAN S. MORA-SANGUINETTI, MARTA MARTÍNEZ-MATUTE and MIGUEL GARCÍA-POSADA: Credit, crisis and contract enforcement: evidence from the Spanish loan market.

1631 PABLO BURRIEL and ALESSANDRO GALESI: Uncovering the heterogeneous effects of ECB unconventional monetary policies across euro area countries.

BANCODEESPAÑA

Eurosistema
Unidad de Servicios Auxiliares

Alcalá, 48 - 28014 Madrid

E-mail: publicaciones@bde.es www.bde.es 